\title{
Intraspecific kin recognition contributes to interspecific allelopathy:A case study of allelopathic rice interference with paddy weeds
}

\author{
You Xu ${ }^{1}$, Huifang Cheng $^{1}$, Chuihua Kong ${ }^{2}$, and Scott Meiners ${ }^{3}$ \\ ${ }^{1}$ China Agricultural University College of Resources and Environmental Sciences \\ ${ }^{2}$ China Agricultural University \\ ${ }^{3}$ Eastern Illinois University
}

March 19, 2021

\begin{abstract}
Species interactions and mechanisms affect plant coexistence and community assembly. Despite increasing knowledge of kin recognition and allelopathy in regulating interspecific and intraspecific interactions among plants, little is known about whether kin recognition mediates allelopathic interference. We used allelopathic rice cultivars with the ability for kin recognition grown in kin vs. non-kin mixtures to determine their impacts on paddy weeds in field trials and a series of controlled experiments. We experimentally tested potential mechanisms of the interaction via altered root behavior, allelochemical production, and soil microbial community composition, as well as carbon and nitrogen partitioning in the weeds. We consistently found that the establishment and growth of paddy weeds were more inhibited by kin mixtures compared to non-kin mixtures. The effect was driven by kin recognition that induced altered root placement, established similar soil microbial communities, and altered weed carbon and nitrogen partitioning. Importantly, genetic relatedness enhanced the production of intrusive roots towards weeds and reduced the production of rice allelochemicals. These findings suggest that relatedness allows allelopathic plants to discriminate their neighboring collaborators (kin) or competitors and then adjust their growth, competitiveness and chemical defense accordingly.
\end{abstract}

Intraspecific kin recognition contributes to interspecific allelopathy:A case study ofallelopathic rice interference with paddy weeds

You Xu ${ }^{1}$, Hui-Fang Cheng ${ }^{1}$, Chui-Hua Kong ${ }^{1^{*}}$ and Scott J. Meiners ${ }^{2}$

${ }^{1}$ College of Resources and Environmental Sciences, China Agricultural University, Beijing 100193, China

${ }^{2}$ Department of Biological Sciences, Eastern Illinois University, Charleston, IL 61920, USA

Running head: Kin recognition in allelopathic rice against weeds

*Corresponding author: C.H. Kong, College of Resources and Environmental Sciences, China Agricultural University, Beijing 100193, China. Tel: +86-10-62732752; fax: +86-10-62731016, E-mail: kongch@cau.edu.cn

Figure numbers: 8

Supplementary Figure numbers: 7

Supplementary Table numbers: 2

Abstract 
Species interactions and mechanisms affect plant coexistence and community assembly. Despite increasing knowledge of kin recognition and allelopathy in regulating interspecific and intraspecific interactions among plants, little is known about whether kin recognition mediates allelopathic interference. We used allelopathic rice cultivars with the ability for kin recognition grown in kin vs. non-kin mixtures to determine their impacts on paddy weeds in field trials and a series of controlled experiments. We experimentally tested potential mechanisms of the interaction via altered root behavior, allelochemical production, and soil microbial community composition, as well as carbon and nitrogen partitioning in the weeds. We consistently found that the establishment and growth of paddy weeds were more inhibited by kin mixtures compared to non-kin mixtures. The effect was driven by kin recognition that induced altered root placement, established similar soil microbial communities, and altered weed carbon and nitrogen partitioning. Importantly, genetic relatedness enhanced the production of intrusive roots towards weeds and reduced the production of rice allelochemicals. These findings suggest that relatedness allows allelopathic plants to discriminate their neighboring collaborators (kin) or competitors and then adjust their growth, competitiveness and chemical defense accordingly.

\section{KEYWORDS}

allelopathic rice cultivar, allelochemical production, resource partitioning, kin and non-kin cultivar mixtures, neighbor relatedness, root placement pattern, soil microbial community

\section{INTRODUCTION}

Understanding the mechanisms of co-occurring species interactions in plant coexistence and community assembly has been of great interest to ecologists for decades (Maron, Hahn, Hajek, \& Pearson, 2020; Tilman \& Pacala, 1993). When one or more species occur together and interact, plants may detect and recognize their neighbors, potentially differentiating interspecific individuals from conspecific individuals (Gruntman \& Novoplansky, 2004), and even intraspecifically between kin and non-kin individuals (Dudley \& File, 2007). Following neighbor detection and recognition, plants may adjust their growth and defense strategies, altering plant coexistence and community assembly (Wang, Kong, Wang, \& Meiners, 2020).

The role of plant-plant interactions in regulating coexistence has been a fundamental issue within ecology and evolution, focusing predominately on interspecific and intraspecific competition (Bennett, Riibak, Tamme, Lewis, \& Partel, 2016; Genung, Bailey, \& Schweitzer, 2012; Yamawo \& Mukai, 2020). In recent decades, this issue research has expanded to include both kin recognition and allelopathy (Bilas, Bretman, \& Bennett, 2020; Kong et al., 2018). Kin recognition may allow plants to optimize competitive strategies, resulting in less intraspecific competition and more cooperation among plants, maximizing stand performance (Bilas, Bretman, \& Bennett, 2020; Dudley, Murphy, \& File, 2013). Kin recognition in crop cultivars may also be exploited to improve crop yields (Anten, \& Chen, 2021; Murphy, Swanton, van Acker, \& Dudley, 2017). In contrast to the altruism of intraspecific kin recognition, allelopathy is an interference mechanism in which plants produce and release allelochemicals exerting a mostly negative effect on interspecific or intraspecific neighbors. Such allelopathic interferences can have profound effects on the performance of neighboring plants and alter local plant coexistence (Meiners, Kong, Ladwig, Pisula, \& Lang, 2012; Zhang, Liu, Yuan, Weber, \& van Kleunen, 2020). Noteworthily, different from competition for taking up shared resources, allelopathy is a chemical strategy in the defense of plant against competing neighbors, which results from the allelochemicals produced and released from plants themselves (Macías, Mejías, \& Molinillo, 2019).

Both kin recognition and allelopathy have been investigated extensively in natural and managed ecosystems (Anten, \& Chen, 2021; Inderjit, Wardle, Karban, \& Callaway, 2011; Macías, Mejías, \& Molinillo, 2019; Serra, Shanmuganathan, \& Becker, 2021). However, kin recognition and allelopathic interference are usually studied separately, with no attention to their potential linkage. Plants often grow in mixtures of kin, non-kin conspecifics, and individuals from different species, and thus kin recognition and interspecific allelopathic interference may often occur simultaneously. Accordingly, kin recognition may interact with allelopathic interference within a heterogenous community context. Ultimately, understanding the interactions between kin recognition and allelopathic interference in diverse natural systems will depend on initial efforts from 
simplified agroecosystems.

Crop plants have coexisted with weeds in agroecosystems for thousands of years and can act as models for addressing eco-evolutionary dynamics in plant coexistence (Baucom, \& Holt, 2009). Weeds pose an important biological constraint to crop productivity while only a few crop cultivars are very competitive against weeds. However, the weed-suppressive effects have not been fully explained by considering just the physical characteristics of being strong in competition for resources (Bastiaans, Kropff, Kempuchetty, Rajan, \& Migo, 1997; Olofsdotter, Navarez, Rebulanan, \& Streibig, 1999). Subsequent studies have shown the participation of allelopathy. In particular, allelopathic crop cultivars can detect the presence of weeds and respond by increasing allelochemicals to inhibit weeds, maximizing their own growth (Kato-Noguchi, 2011; Kong et al., 2018; Kong, Li, Hu, Xu, \& Wang, 2006). Therefore, crop-weed interactions are not only of fundamental ecological interest, but also exceedingly important from an applied perspective in sustainable agriculture.

Rice ( $O$ ryza sativa) is one of the principal food crops in the world, containing both allelopathic and non-allelopathic cultivars. Allelopathic rice cultivars can produce and release allelochemicals to inhibit the growth and establishment of paddy weeds, acting as an efficient component of integrated weed management (Kong, Hu, Wang, \& Wu, 2008; Patni et al., 2018; Serra, Shanmuganathan, \& Becker, 2021). Recent studies have shown kin recognition in rice cultivars (Fang et al., 2013) and allelopathic rice cultivars with the ability for kin recognition can alter root behavior and biomass allocation, increasing grain yields (Yang, Li, $\mathrm{Xu}$, \& Kong, 2018). Therefore, allelopathic rice interference with paddy weeds represents a well-characterized model system to understand the combined roles of kin recognition and interspecific allelopathy in plant-plant interactions.

There is a wealth of information on allelopathic rice interference with paddy weeds under field situations and controlled conditions (Gealy, Rohlla, \& Boykin, 2019; Kato-Noguchi, 2011; Kong, Hu, Wang, \& Wu, 2008; Li, Zhao, \& Kong, 2020). However, when it comes to the role of kin recognition in allelopathic rice interference with paddy weeds, there is a lack of data. Such information is critical for understanding the consequences and mechanisms of plant coexistence in the given ecosystem. In this study, we identify the potential linkage between kin recognition and allelopathic interference in a rice paddy model system, to test two specific hypotheses (1) whether kin recognition can alter the consequences of interspecific allelopathic interference, and (2) whether relatedness allows allelopathic plants to discriminate between neighboring collaborators (kin) and competitors by altering biochemical plasticity and then adjust their growth, competitiveness, and chemical defense. To do this, we examined the effects of allelopathic rice cultivars with the ability for kin recognition from two sets of indica-inbred and indica-hybrid rice lines against paddy weeds in field and controlled conditions. Furthermore, we addressed potential mechanisms through documenting changes in root behavior, allelochemical production, associated soil microbial communities, and the carbon and nitrogen partitioning of weeds. Together, these efforts provide a thorough assessment of the contribution of kin recognition to allelopathic interference, and its implications for plant coexistence and community assembly.

\section{MATERIALS \& METHODS}

\subsection{Plant materials, soil and chemicals}

Seven rice (Oryza sativa ) cultivars, Huagan-3, Huagan-8, Huafeng, Lingyou-6173, Lingyou-6365, Lingyou3826 and Liaojing, were used for this study. Among them, allelopathic Huagan-3 and Lingyou-6173 have the ability for kin recognition (Yang, Li, Xu, \& Kong, 2018), and other cultivars are non-allelopathic. 'Huagan-3' and 'Huagan-8' or 'Lingyou-6173' and 'Lingyou-6365' were bred or hybridized from reciprocal parents or identical male sterile, resulting in their relatedness. 'Huafeng' or 'Lingyou-3826' was obtained from other parents or male sterile that do not have consanguinity ties with the 'Huagan-3' and 'Huagan-8' or 'Lingyou6173' and 'Lingyou-6365'. These cultivars with different relatedness were divided into two sets of genotypes, indica-inbred and indica-hybrid. In the indica-inbred rice set, 'Huagan-3' was the focal rice cultivar (same cultivar, self). 'Huagan-8' and 'Huafeng' were the closely related (kin) and distantly related (non-kin) culti- 
vars, respectively. In indica-hybrid rice set, 'Lingyou-6173' was the focal rice cultivar (same cultivar, self). 'Lingyou-6365' and 'Lingyou-3826' were the closely and distantly related cultivars, respectively. In addition, a japonica-inbred cultivar 'Liaojing' was used for comparative evaluation as a more distant non-kin for both sets. Finally, the relatedness of cultivars in both sets was determined by genetic distances relative to the focal cultivar (Yang, Li, Xu, \& Kong, 2018). The genetic distance, allelopathic potential and grain biomass of these cultivars were presented in Supplementary Table 1.

Weeds seeds and soil were collected at Nanling experimental station of rice research, Anhui Province, China $\left(30^{\circ} 56^{\prime} 52^{\prime \prime} \mathrm{N}, 118 \mathrm{deg} 23^{\prime} 15^{\prime}\right.$ " E), located in the low mountains on the southern side of the Yangtze River. Soil was collected randomly from the surface $(0-10 \mathrm{~cm})$ of a paddy field. The soil is typical fluvaquent, Etisol (US taxonomy) with $\mathrm{pH} 5.6$, organic matter of $24.5 \mathrm{~g}^{*} \mathrm{~kg}^{-1}$ and a fertility for total nitrogen of $1.4 \mathrm{~g}^{*} \mathrm{~kg}^{-1}$, available phosphourus of $29.3 \mathrm{mg}^{*} \mathrm{~kg}^{-1}$ and available potassium of $56.8 \mathrm{mg}^{*} \mathrm{~kg}^{-1}$. Soil samples were air-dried, sieved (2 $\mathrm{mm}$ mesh) to remove plant tissues, and used in the series of greenhouse experiments described below.

The rice allelochemicals tricin and momilactone B were isolated from allelopathic rice PI312777 seedlings following Kong et al. (2004). Allantoin, related to kin recognition in rice lines (Yang, Li, Xu, \& Kong, 2018), and other chemicals were purchased from China National Chemical Corporation (Beijing, China) and were of the highest purity available.

\subsection{Field trials}

A paddy field was selected at the experimental station during the 2020 growing season. The paddy had previously been planted with rice for several seasons. Several weeds occurred in the paddy, includingEchinochloa crusgalli (barnyardgrass), Leptochloa chinensis , Cyperus difformis and Eclipta prostrata but barnyardgrass was dominant. Other weedy species such asAlternanthera sessilis and Monochoria vaginalisoccasionally occurred in the field. The field was divided into a series of $3 \times 5 \mathrm{~m}$ plots arranged in a completely randomized design with four replicates of each treatment or control. Each plot was separated by trenches with at least $30 \mathrm{~cm}$ discard strips on each side. Each focal cultivar 'Huagan-3' or 'Lingyou-6173' was paired with itself, or with a closely or distantly related cultivar, and planted at a density of $50 \mathrm{~m}^{-2}$ by direct seeding at a 1:1 proportion. Plots not planted with rice served as controls for weed growth. All plots received fertilizer (nitrogen, phosphorus pentoxide, and potassium oxide at the rates of $7.5 \mathrm{~g} \mathrm{~m}^{-2}, 9.0 \mathrm{~g} \mathrm{~m}^{-2}$ and $8.5 \mathrm{~g} \mathrm{~m}^{-2}$ respectively) 1 day before the plots were saturated with water. All other field management followed the rules of the rural administration in Anhui Province, China except chemical or hand weeding. After 50 days, weed species and numbers in each plot were identified and their aboveground biomass dry weights measured.

\subsection{Greenhouse experiments}

A series of experiments were conducted in a greenhouse with 20-30 degC night and day temperatures and $65-90 \%$ relative humidity. Each experiment was conducted in a completely randomized design with four replicates for each treatment and control. Rice seeds were sterilized with $5 \% \mathrm{H}_{2} \mathrm{O}_{2}$ then placed in Petri dishes with moistened filter paper. Weed seeds were sterilized with $75 \%$ ethyl alcohol for 3 min, followed with $3 \%$ sodium hypochlorite for $12 \mathrm{~min}$. Sterilized seeds were rinsed with distilled water and then transferred to Petri dishes with moistened filter paper for vernalization in a $4 \mathrm{degC}$ refrigerator for $24 \mathrm{~h}$. Dishes of rice and vernalized weed seeds were pre-germinated in an environmentally controlled chamber at a temperature of $28 \mathrm{deg} \mathrm{C}$ in the dark for use in each experiment.

A preliminary experiment was conducted to investigate the effect of rice cultivar mixture proportions on four common paddy weeds (barnyardgrass, L. chinensis, C. difformis and E. prostrata). Eight pre-germinated seeds were sown in each pot $(12 \mathrm{~cm}$ diameter x10 cm deep) containing $1000 \mathrm{~g}$ soil. Four rice seeds in a 3:1, 2:2 and 1:3 (focal cultivar: related cultivar) ratio were placed uniformly in the central area while four weed seeds of one species were sown surrounding the rice in the pot (Supplementary Figure 1). Monocultures of eight weed seeds served as controls. The weed seedlings were harvested after 4 weeks and their dry weights were recorded. This design was replicated for each focal cultivar and weed species. As a result (Supplementary Table 2), the 2:2 ratio was used for each subsequent experiment (Experiments 1- 4) as described below. 
Experiment 1- the effect of rice cultivar mixtures on the performance of four weeds and their mixtures with barnyardgrass. Eight pre-germinated seeds were sown in each pot as described above. Four rice seeds for each cultivar pair were placed uniformly in the central area of each pot. Four weed seeds for each species, or two barnyardgrass with two other weed seeds, were sown surrounding the rice. Controls were monocultures of eight weed seeds for each species and their mixtures with barnyardgrass. Mixtures with barnyardgrass reflect the dominance of the species as a paddy weed and its regular co-occurrence with other weeds. Weed seedlings were harvested at the three-leaf rice stage and their shoots and roots were separated and dry weight of each was recorded.

Experiment 2- allelochemical production and grain biomass of rice cultivar mixtures in response to barnyardgrass and its mixtures with other weeds. Eight pre-germinated seeds were sown in a pot as described above. Four rice seeds for each cultivar pair were placed uniformly in the central area. Four barnyardgrass seeds or two barnyardgrass with two other weed seeds were sown surrounding the rice in each pot. Monocultures of each rice cultivar and eight weed seeds for each species and their mixtures with barnyardgrass served as controls. Allelopathic rice leaves produce allelochemicals at their early growth stages and then release them into soil through the roots that reach maximal level at the five-leaf stage and then decrease dramatically (Kong et al., 2004; Kong, Li, Hu, Xu, \& Wang, 2006). This experiment focused on allelochemical production but not allelochemical release. Accordingly, rice leaves were sampled at the three-leaf stage and quantification of rice allelochemicals conducted as described below. Weed plants and rice grains were each harvested at the rice mature stage and their dry weight of each was recorded.

Experiment 3- soil microbial community in response to rice cultivar mixtures in the presence of barnyardgrass, the dominant weed competitor. Eight pre-germinated seeds were sown in each pot as described above. Four rice seeds for each cultivar pair were placed uniformly in the central area. Four barnyardgrass seeds were sown surrounding the rice in the pot. Monocultures of barnyardgrass or focal rice cultivar served as controls. At the three-leaf stage, a soil core with $2.5 \mathrm{~cm}$ diameter and $5 \mathrm{~cm}$ depth was sampled from the central area of each pot. Visible root fragments were removed and the sample freeze-dried for the analysis of phospholipid fatty acids (PLFA) as described below.

Experiment 4- the performance and resource partitioning of barnyardgrass in response to potential signalingchemical in rice cultivar mixtures. Kin recognition in allelopathic rice cultivars involves the nitrogen-rich compound allantoin (Yang, $\mathrm{Li}, \mathrm{Xu}, \&$ Kong, 2018). Accordingly, allantoin and its equal quantity of $\mathrm{NH}_{4} \mathrm{NO}_{3}$ were applied into rice cultivar mixtures in the presence of barnyardgrass. Eight pre-germinated seeds were sown in each pot $(12 \mathrm{~cm} \mathrm{x10} \mathrm{cm})$ containing $1000 \mathrm{~g}$ soil. Four rice seeds for each cultivar pair were placed uniformly in the central area of each pot. Four barnyardgrass seeds were sown surrounding the rice in the pot and monocultures of barnyardgrass served as controls. The pots received either allantoin at a concentration of $0.32 \mathrm{mM}\left(50 \mu \mathrm{g} \mathrm{g} \mathrm{g}^{-1}\right.$ dry soil), $\mathrm{NH}_{4} \mathrm{NO}_{3}$ at a concentration of $0.63 \mathrm{mM}$ (50 $\mu \mathrm{g} \mathrm{g}^{-1}$ dry soil), or distilled water, respectively. The $\mathrm{NH}_{4} \mathrm{NO}_{3}$ treatment represents a non-signaling nitrogen source to contrast with the signaling and high $\mathrm{N}$ content allantoin treatment. Barnyardgrass seedlings were harvested at three-leaf stage, separating their shoots and roots. The dry weights of each root and shoot sample were recorded and their carbon and nitrogen contents were each measured with a CN elemental analyzer (Elementar vario EL cube, Elementar Analysensysteme GmbH, Langenselbold, Germany), at a combustion temperature of 960 .

Experiment 5- root placement patterns between focal rice cultivar and weeds in response to rice cultivars of different relatedness. A series of window rhizoboxes $(30 \mathrm{~cm}$ long $\times 3 \mathrm{~cm}$ wide $\times 30 \mathrm{~cm}$ high $)$ were made with a clear plexiglass sheet containing $2000 \mathrm{~g}$ soil. Each rhizobox was vertically divided into six equal parts, and three rice and three weeds for each species were sown in the rhizoboxes according to the order of two plants of related cultivars, a plant of the focal cultivar, and three weed plants from the left to the right (Supplementary Figure 2). Monocultures of six plants barnyardgrass or focal cultivars served as controls. Window rhizoboxes were placed in racks at an angle of $40^{\circ}$ with the clear plexiglass facing down and away from the light source. Rhizoboxes were opened after 4 weeks and the root systems were scanned to a gray scale image and, divided into right and left parts, and the roots freeze-dried for biomass assessment. Each image was processed with WINRHIZO (Regent Instruments, Quebec, Canada) to obtain root length, and 
horizontal asymmetry in root length. Horizontal asymmetry in root biomass was also calculated from root dry weight of the left (towards rice) and right (towards weed) halves of the root system.

\subsection{Quantification of rice allelochemicals}

Quantification of allelochemicals from focal rice cultivars 'Huagan-3' and 'Lingyou-6173' was performed with a liquid extraction-solid phase extraction followed by High Performance Liquid Chromatography (HPLC). The rice samples collected from the experiment 2 were freeze-dried and ground, and $20 \mathrm{mg}$ was extracted with $10 \mathrm{~mL} \mathrm{MeOH}$ for $12 \mathrm{~h}$ and filtered. The filtrates were evaporated to dryness individually under nitrogen gas. Dry residues were dissolved in $2 \mathrm{~mL} 50 \%$ aqueous methanol then filtered through a $0.22 \mu \mathrm{m}$ filter. The filtered samples were subsequently subjected to HPLC for quantitative analysis.

Quantitative analysis was carried out by injecting $10 \mu \mathrm{L}$ into an HPLC (HPLC-1525; Waters, Worcester, MA, USA) with a UV detector set at $320 \mathrm{~nm}$. Elution was performed at a constant flow rate of $1.0 \mathrm{~mL}$ $\mathrm{min}^{-1}$ at 40 with acetonitrile and a mixture of $0.5 \%$ formic acid in a gradient: initial mobile phase of $10 \%$ acetonitrile for $4 \mathrm{~min}$, increased to $35 \%$ for $4 \mathrm{~min}$, then decreased to $10 \%$ for $4 \mathrm{~min}$, for a total run time of $12 \mathrm{~min}$. The allelochemicals tricin and momilactone B were quantified by interpolating the peak area on the HPLC chromatogram to a standard curve constructed from the peak area of authentic tricin and momilactone B (Yang \& Kong, 2017).

\subsection{PLFA analysis}

The soil samples collected from the experiment 3 were subjected to PLFA analysis that was conducted following method of Sun et al. (2014) with minor modifications. Briefly, freeze-dried soil was extracted with a mixture of $\mathrm{CHCl}_{3}-\mathrm{MeOH}$-citrate butter $(1: 2: 0.8, \mathrm{v} / \mathrm{v} / \mathrm{v})$, and the phospholipids were separated from other lipids on a silica-gelfilled solid-phase extraction cartridge (0.50 g Si; Supelco, Inc., Bellefonte, PA, USA). The resulting fatty acid methyl esters (FAMEs) were identified and quantified by GC-MS. The identification of the FAMEs was based on retention time comparisons with FAMEs controls (Supelco, Inc., Bellefonte, PA, USA). Quantification was performed by calibration against standard solutions of nonadecanoate methylester (C19:0), which were also considered as internal standards.

A total of 16 PLFAs were identified and quantified for the analysis. Twelve fatty acids (i-15:0, a-15:0, i-16:0, i-17:0, 16:1 $\omega 7 \mathrm{c}, 16: 1 \omega 9 \mathrm{c}, \mathrm{cy}-17: 0,14: 0,15: 0,16: 0,17: 0$ and 18:0) were considered as bacterial. Among them, four fatty acids (i-15:0, a-15:0, i-16:0 and i-17:0) were identified as Gram-positive bacteria $\left(\mathrm{Gram}^{+}\right)$and 3 fatty acid $\left(16: 1 \omega 7 \mathrm{c}, 16: 1 \omega 9 \mathrm{c}\right.$ and cy-17:0) were identified as Gram-negative bacteria $\left(\mathrm{Gram}^{-}\right)$. Fungi were

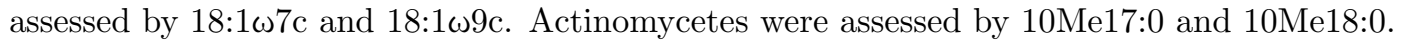

\subsection{Data analysis}

Data were presented as means \pm standard error (SE) from four replications for each experiment and determination. The data were analyzed by full factorial ANOVAs followed by Tukey's honestly significantly different $(\mathrm{HSD})$ tests. Weed inhibition and allelochemical production were calculated as $(1-\mathrm{T} / \mathrm{C}) \times 100$, based on weed dry weights or allelochemical quantity in treatments $(\mathrm{T})$ and in controls $(\mathrm{C})$. Horizontal asymmetry in root length and biomass were calculated as response ratios Vn/Va (Yang \& Kong, 2017). Vn is the response value for rice-weed interactions while $\mathrm{Va}$ is the response value for rice or weed alone. $\mathrm{Vn} / \mathrm{Va}>1$ represented root growth increased towards neighbors, resulting an intrusive pattern of root placement. Vn/Va $<1$ represented root growth decreased towards their neighbors and $\mathrm{Vn} / \mathrm{Va}=1$ represented an unaltered pattern of root growth. Principal component analysis (PCA) of PFLA data was performed with the STATISTICA software package, version 6.0 (StatSoft Inc., USA). Data were transformed using sample unit totals to represent the relative abundance of each PLFA (mole percentage of total PLFA). All data analyses were conducted with SPSS 25.0.

\section{RESULTS}

\subsection{Kin recognition in allelopathic rice interference with paddy weeds}


When allelopathic rice cultivars were each paired with itself or other rice cultivars, the growth of four common paddy weeds (Echinochloa crusgalli, Leptochloa chinensis, Cyperus difformis andEclipta prostrata) were inhibited. However, inhibitory effects were dependent on the genetic relatedness and proportions of rice cultivars. The mixtures with closely related cultivars (kin) had stronger weed inhibition than the mixtures with distantly related cultivars (non-kin) regardless of proportions or weed species. Significant inhibition occurred at the 2:2 proportion with an exception of the broadleaf weed E. prostrata (Supplementary Table 2).

When each mixture of allelopathic rice cultivars with other cultivars at different levels of genetic relatedness was grown in a paddy field at a 1:1 proportion, the emergence and growth of paddy weeds varied greatly in mixed culture with kin and non-kin cultivars (all weeds pooled, Figure 1). Allelopathic rice cultivars grown alone and with kin cultivars showed stronger weed inhibition than when grown with non-kin cultivars. Compared with allelopathic rice cultivars and their mixtures with kin cultivars, a significant reduction in weed inhibition occurred in the mixtures with non-kin cultivars. The results implied the role of kin recognition in mediating allelopathic rice interference with paddy weeds.

\subsection{Kin recognition meditated allelopathic rice against weeds at the root level}

Greenhouse experiment 1 further confirmed that rice cultivars inhibited the growth of paddy weeds and that the inhibition was dependent on the genetic relatedness of the mixture (Figure 2). Allelopathic rice cultivars grown with kin cultivars caused stronger weed inhibition than mixtures with non-kin cultivars. Regardless of weed species and the genetic relatedness of rice cultivars, there was always stronger inhibition in root growth than in shoot growth of weeds (Figure 2). Further, rhizobox experiment 5 revealed that rice and weeds showed different root placement patterns measured by horizontal asymmetry in response to interacting neighbors. (Supplementary Figure $3 \& 4$ ). Rice roots always grew towards the roots of weeds (intrusive pattern), while the roots of all weeds trended to avoid growing towards roots of rice (avoidance pattern). However, root placement patterns between rice cultivars depended on genetic relatedness. Focal rice cultivars grown by themselves or with closely related cultivars had a more root intrusion towards paddy weeds than when grown with distantly related cultivars (Figure 3). Similarly, the largest avoidance by weed roots occurred in allelopathic cultivars grown by themselves or in mixture with closely related cultivars (Figure 4). These results indicated that kin recognition in allelopathic rice could regulate belowground interactions with weeds by optimizing root placement and distribution.

\subsection{Impact of kin recognition on weed-induced rice allelochemical production}

Weed inhibition of allelopathic rice cultivars mainly results from rice allelochemicals. Furthermore, the presence of paddy weeds can induce the production of rice allelochemicals (Kato-Noguchi, 2011; Kong, Li, Hu, $\mathrm{Xu}$, \& Wang, 2006; Li, Zhao, \& Kong, 2020). In experiment 2, when allelopathic rice cultivars were grown in the presence of paddy weeds, the weed-induced rice allelochemical (tricin and momilactone B) production was lowered in cultivar mixtures. In particular, the mixture with closely related cultivars always led to a greater reduction in the production of allelochemicals regardless of the presence of the dominant weed barnyardgrass (Echinochloa crusgalli ) or its mixtures with other paddy weeds (Figure 5). Though mixtures with closely related cultivars significantly reduced the production of rice allelochemicals, weed inhibition were increased (Supplementary Figure 5) and rice grain biomass were not significantly altered (Supplementary Figure 6 ). These results revealed that kin recognition within the rice cultivar mixtures could lower allelochemical defense cost but increase or maintain weed inhibition and rice grain biomass.

\subsection{Soil microbialcharacteristics of rice cultivar mixture with barnyardgrass}

The alteration of root placement patterns and allelochemical production by rice cultivars impacted soil microbial characteristics. In experiment 3, when allelopathic rice cultivars and their mixtures with kin and non-kin cultivars were grown in the presence of barnyardgrass, there were changes in soil microbial characteristics. PLFA profiling showed that the signature of lipid biomarkers of bacteria, fungi and actinomycetes were affected by the genetic relatedness of rice cultivar mixtures (Supplementary Figure 7). The relative abundances of bacterial PLFA (16:0) were significantly greater in the soil of allelopathic cultivars grown with 
closely related cultivars than distantly related cultivars. By contrast, PLFA (18:1 $\omega 7 \mathrm{c})$ and PLFAs (10Me17:0, 10Me18:0) respectively belonging to fungi and actinomycetes, were reduced in the soil of allelopathic cultivars grown with closely related cultivars than distantly related cultivars (Supplementary Figure 7). PCA scores for the PLFA extracted from samples were clearly distinguished by the genetic relatedness of rice cultivar mixtures. The composition of soil microbial groups of allelopathic cultivars grown alone was similar when mixed with closely related cultivars and differed greatly from those mixed with distantly related cultivars. The first two principal components of PFLA composition together accounted for $77.12 \%$ (Huagan-3) and $68.97 \%$ (Lingyou-6173) of the variation in the sets of indica-inbred and indica-hybrid genotypes, respectively (Figure 6). The results indicated that the genetic relatedness of rice cultivar mixtures also determined soil microbial characteristics.

\subsection{Role of allantoin in inhibition andresourcepartitioning of barnyardgrass with rice cultivar mixtures}

In experiment 4, with or without application of a $\mathrm{N}$-fertilizer $\mathrm{NH}_{4} \mathrm{NO}_{3}$, allelopathic rice cultivars and their mixtures with closely related cultivars inhibited the growth of barnyardgrass to a greater extent than the mixtures with distantly related cultivars. However, the inhibition was not observed when the nitrogen-rich compound allantoin was applied (Figure 7). Furthermore, there were different changes in carbon and nitrogen partitioning in barnyardgrass under application of $\mathrm{NH}_{4} \mathrm{NO}_{3}$ and allantoin. Relative to monocultures, barnyardgrass grown with rice had increased root carbon and nitrogen. In particular, kin cultivar mixtures had a higher root/shoot carbon and nitrogen ratios of barnyardgrass than non-kin cultivar mixtures. Compared with control (without $\mathrm{N}$ ), $\mathrm{NH}_{4} \mathrm{NO}_{3}$ induced carbon and nitrogen partitioning of barnyardgrass from shoot into roots. However, the carbon and nitrogen partitioning were not altered by allantoin (Figure 8). The results indicated that allantoin did not served as a $\mathrm{N}$-fertilizer for the inhibition and resource partitioning of barnyardgrass by rice cultivar mixtures.

\section{DISCUSSION}

Intraspecific genetic variation can have important ecological consequences for interspecific interactions (Ehlers, David, Damgaard, \& Lenormand, 2016; Fridley \& Grime, 2010; Genung, Bailey, \& Schweitzer, 2012). Kin recognition and allelopathic interference are important mediators of interspecific or intraspecific interactions among plants (Bilas, Bretman, \& Bennett, 2020; Dudley, Murphy, \& File, 2013; Kong et al., 2018; Wang, Kong, Wang, \& Meiners, 2020). From a model system of allelopathic rice interference with paddy weeds, this study presents the first evidence that intraspecific kin recognition may have consequences for interspecific allelopathic interference. In particular, this study makes the case for a novel mechanism: that reductions in the costs associated with intraspecific interactions with kin allow increased interspecific allelopathic inhibition of co-occurring weeds. The direct evidence and mechanisms were that, when grown with closely related cultivars, there was (1) increased weed inhibition, maintaining rice grain biomass; (2) reduced production of rice allelochemicals, lowering defense cost; (3) altered root placement towards weeds, reconciling niche partitioning and competitive ability; (4) generated similar soil microbial community structure; and (5) altered carbon and nitrogen partitioning of weed species.

A plant may interfere with neighboring plant growth and establishment directly through competition, allelopathy, or both. In allelopathic rice against paddy weeds, the weed-suppressive effect is a combination of allelochemical action and interspecific competition (Kong, Hu, Wang, \& Wu, 2008). Allelopathy and competition are well known to regulate inter- and intra-specific interactions and community assembly (Fernandez et al., 2016; Inderjit, Wardle, Karban, \& Callaway, 2011; Xia, Kong, Chen, Wang, \& Wang, 2016). An increasing number of studies have shown that kin recognition in plants can also alter the outcome of intraspecific and interspecific competition and determine species coexistence (Dudley, Murphy, \& File, 2013; Ehlers, David, Damgaard, \& Lenormand, 2016; Yamawo \& Mukai, 2020). In some plant communities, there is a reciprocal relationship between competition and intraspecific trait variation (Bennett, Riibak, Tamme, Lewis, \& Partel, 2016). In particular, intraspecific genetic relatedness may be more important than variation among species in determining species coexistence (Ehlers, David, Damgaard, \& Lenormand, 2016; Fridley \& Grime, 2010). These studies have revealed the linkage between kin recognition and competition in plant 
coexistence and community assembly. In the current study, we extend this observation to both competition and allelopathy. Intraspecific genetic relatedness in rice enhanced root intrusive behavior towards paddy weeds, affecting competition and allelopathy. Furthermore, kin recognition reduced the production of allelochemicals in rice cultivar mixtures with closely related cultivars. Root inhibition of paddy weeds mainly result from allelochemicals and intrusive roots of allelopathic rice cultivars generating avoidance patterns in weed roots (Yang \& Kong, 2017). This study highlights that kin mixtures result in stronger root inhibition and avoidance growth of paddy weeds than non-kin cultivar mixtures, even with reduced production of allelochemicals. Therefore, weed inhibition appears to be generated by targeted kin recognition through altered root placement, reconciling niche partitioning and competitive ability, rather than an overall upregulation of allelochemicals.

Allelopathic rice cultivars produce and release allelochemicals against paddy weeds. However, the production of allelochemicals must also incur a defense cost, subsequently generating a trade-off between growth and defense (Meiners, Kong, Ladwig, Pisula, \& Lang, 2012). A plant can change its defensive strategy based on the identity of its neighbors (Broz et al., 2010; Metlen, Aschehoug, \& Callaway, 2009; Pierik, Mommer, $\&$ Voesenek, 2013). The production of allelochemicals also depends on co-occurring plant species (Kong et al., 2018; Ormeno, Fernandez, \& Mevy, 2007; Xia, Kong, Chen, Wang, \& Wang, 2016). The production of allelochemicals may be decreased in the presence of a "good" neighbor like the kin cultivars in this study, representing a benefit to the allelopathic plant while maintaining a reduced cost to the kin.

Plant neighbor recognition and allelochemical responses have been well documented between species (Kong et al., 2018;Lankau \& Strauss, 2007; Pierik, Mommer, \& Voesenek, 2013), but less is known about intraspecific kin and non-kin interactions. Several studies have shown that relatedness of neighboring plants mediates the expression of indirect defense traits (Karban, Shiojiri, Ishizaki, Wetzel, \& Evans, 2013; Kalske, Shiojiri, Uesugi, Sakata, \& Kessler, 2019; Yamawo, 2015). However, these studies have been primarily in the context of herbivore-induced defenses rather than direct plant-plant interactions. Data generated in this study revealed that kin recognition also affect chemical defenses in plant-plant interactions, reducing the production of allelochemicals in the presence of close relatives, shifting allocation from defense into growth.

Plants differentiate their neighbors based on genetic relatedness and alter functional traits in response to intraspecific competition (Donohue, 2003; Dudley, Murphy, \& File, 2013). Functional trait responses can result in kin facilitation and cooperative behavior (Ehlers, David, Damgaard, \& Lenormand, 2016). Functional changes in response to the presence of kin particularly alter patterns of root growth and distribution (Semchenko, John, \& Hutchings, 2007; Semchenko, Saar, \& Lepik, 2014), ameliorating the negative effects of root competition (File, Murphy, \& Dudley, 2012). Roots from distantly related rice plants may grow towards each other while closely related roots exhibit avoidance, minimizing intraspecific competition (Yang, Li, Xu, \& Kong, 2018). Reduced competition among kin in cultivar mixtures allowed individuals to better cope with interspecific competition.

Soil microorganisms may contribute to the coexistence of plant species (Miki, Ushio, Fukui, \& Kondoh, 2010). The effects of kin on rice performance and interaction with weeds may have been partly driven by soil microbial composition. Soil microbial composition is closely associated with plant species and their root exudate metabolites (Hu et al., 2018; Schnitzer et al., 2011). In particular, root exudate metabolites drive plant-soil feedbacks by shaping the rhizosphere microbiota (Hu et al., 2018), impacting plant growth and chemical defense traits (Formenti et al., 2021). In the presence of competing barnyardgrass, allelopathic rice generated cultivar-specific soil microbial communities that can induce positive feedbacks on growth and reproduction (Sun, Wang, \& Kong, 2014). The present data show that kin cultivar mixtures are capable of recruiting and assembling a similar soil microbial community in which they are able to thrive. Kin effects mainly occur in the preferred soil where competitor relatedness alters local soil conditions, causing indirect soil effects on plant coexistence (Ehlers, David, Damgaard, \& Lenormand, 2016). Therefore, kin cultivar mixtures may create a better soil microbial community for rice growth.

An additional source of fitness variation in plants growing with relatives arises from the trade-off in the allocation of plant carbon and nitrogen (File, Murphy, \& Dudley, 2012). Recent studies have indicated 
the importance of nitrogen partitioning and cycling in kin recognition (Semchenko, Saar, S., \& Lepik, 2017; Zhang, Liu, Tian, Xu, \& Ouyang, 2016). In this study, kin cultivar mixtures always had stronger inhibition on barnyardgrass than non-kin cultivar mixtures, regardless of available nitrogen. However, nitrogen application generated carbon and nitrogen allocation shifts of barnyardgrass from shoots into roots. These results imply that nitrogen acquisition and partitioning may function independently in intraspecific kin recognition and interspecific allelopathy.

Allelopathic rice cultivars differentially respond to kin and non-kin by altering the release of nitrogen-rich allantoin, releasing more allantoin in the presence of distantly related cultivars (Yang, Li, Xu, \& Kong, 2018). In this study, allantoin application appeared to alleviate inhibitory differences between kin and nonkin cultivar mixtures and did not affect the carbon and nitrogen partitioning of barnyardgrass. Allantoin may act as a transportable nitrogen or signal to protect plants from stresses (Nourimand \& Todd, 2016), activating the jasmonic acid signaling pathway (Takagi et al., 2016). Rice cultivars produce and release allantoin in response to species interactions (Wang, Kong, Hu, \& Xu, 2007), inducing changes in microbial diversity and community composition in soil (Wang, Kong, Sun, \& Xu, 2010). In this study, allantoin was not a transportable source of nitrogen, but may serve as signaling chemical in response to kin recognition. However, the role of allantoin as a signal of relatedness still needs to be verified in cultivar specific or upstream signals. Allantoin may not be the signal but rather the effect of an unidentified, underlying signal (Wang, Kong, Wang, \& Meiners, 2020).

\section{CONCLUSIONS}

Allelopathic interference and its ecological implications in natural and managed ecosystems have been well established. Recent efforts have made considerable progress towards understanding kin recognition in plantplant interactions. Nevertheless, the role of kin recognition in mediating allelopathic interference remains largely unknown. This study showed that kin recognition may alter the consequences of allelopathic rice interference with paddy weeds. In particular, altruistic responses to kin recognition in rice may contribute to allelopathic interference with paddy weeds. We showed that genetic relatedness allows allelopathic plants to discriminate neighboring collaborators or competitors and adjust their growth, competitiveness and chemical defense accordingly. This work greatly improves our understanding of plant neighbor detection by integrating response strategies to intraspecific and interspecific interactions. However, such responsiveness needs to be explored in other plant systems to determine whether is a general phenomenon or is restricted to allelopathic rice interference with paddy weeds. A thorough understanding of the mechanisms and interactions between intraspecific kin recognition and interspecific allelopathy may offer many ecological implications and potential applications for sustainable agriculture.

\section{ACKNOWLEDGEMENTS}

This work was supported by the National Natural Science Foundation of China (31672040).

\section{CONFLICT OF INTEREST}

The authors declare no conflict of interests.

\section{AUTHOR CONTRIBUTIONS}

C.H.K. conceived and designed the experiments; Y.X. and H.F.C. performed the experiments and collected the data; Y.X. and C.H.K. analyzed the data; C.H.K. wrote the manuscript and S.J.M. edited the manuscript.

\section{REFERENCES}

Anten, N. P. R., \& Chen, B. J. W. (2021). Detect thy family: Mechanisms, ecology and agricultural aspects of kin recognition in plants. Plant, Cell and Environment,https://doi.org/10.1111/pce.14011

Bastiaans, L., Kropff, M. J., Kempuchetty, N., Rajan, A., \& Migo, T. R. (1997). Can simulation models help design rice cultivars that are more competitive against weeds? Field Crop Research, 51(1-2), 101-111. https://doi.org/10.1016/S0378-4290(96)01046-5 
Baucom, R. S., \& Holt, J. S. (2009). Weeds of agricultural importance: bridging the gap between evolutionary ecology and crop and weed science.New Phytologist, 184(4), 741-743. https://doi.org/10.1111/j.14698137.2009.03077.x

Bennett, J. A., Riibak, K., Tamme, R., Lewis, R., \& Partel, M. (2016). The reciprocal relationship between competition and intraspecific trait variation. Journal of Ecology, 104(5), 1410-1420. https://doi.org/10.1111/1365-2745.12614

Bilas, R. D., Bretman, A., \& Bennett, T. (2020). Friends, neighbours and enemies: an overview of the communal and social biology of plants.Plant, Cell and Environment, https://doi.org/10.1111/pce.13965.

Broz, A. K., Broeckling, C. D., De-la-Peña, C., Lewis, M. R., Greene, E., Callaway, R. M., Sumner, L. W., \& Vivanco, J. M. (2010). Plant neighbor identity influences plant biochemistry and physiology related to defense. BMC Plant Biology, 10, 115. https://doi.org/10.1186/1471-2229-10-115

Donohue, K. (2003). The influence of neighbour relatedness on multilevel selection in the Great Lakes sea rocket. American Naturalist,162(1), 77-92. https://doi.org/10.1086/375299

Dudley, S. A., \& File, A. L. (2007). Kin recognition in an annual plant. Biology Letters, 3(4), 435-438. https://doi.org/10.1098/rsbl.2007.0232

Dudley, S. A., Murphy, G. P., \& File, A. L. 2013. Kin recognition and competition in plants. Functional Ecology, 27(4), 898-906.https://doi.org/10.1111/1365-2435.12121

Ehlers, B. K., David, P., Damgaard, C. F., \& Lenormand, T. (2016). Competitor relatedness, indirect soil effects and plant coexistence. Journal of Ecology, 104(4), 1126-1135. https://doi.org/10.1111/1365-2745.12568

Fang, S. Q., Clark, R. T., Zheng, Y., Iyer-Pascuzzi, A. S., Weitz, J., Kochian, L. V., ... Benfey, P. N. (2013). Genotypic recognition and spatial responses by rice roots. Proceedings of the National Academy of Sciences of the United States of America, 110, 2670-2675. https://doi.org/10.1073/pnas.1222821110

Fernandez, C., Monnier, Y., Santonja, M., Gallet, C., Weston, L. A., Prévosto, B., .. Bousquet-Mélou, A. (2016). The impact of competition and allelopathy on the trade-off between plant defense and growth in two contrasting tree species. Frontier in Plant Science, 7, 594. https://doi.org/10.3389/fpls.2016.00594

File, A. L., Murphy, G. P., \& Dudley, S. A. (2012). Fitness consequences of plants growing with siblings: reconciling kin selection, niche partitioning and competitive ability. Proceedings of the Royal Society BBiological Sciences, 279, 209-218. https://doi.org/10.1098/rspb.2011.1995

Formenti, L., Caggìa, V., Puissant, J., Goodall, T., Glauser, G., Griffiths, R., \& Rasmann, S. (2021). The effect of root-associated microbes on plant growth and chemical defence traits across two contrasted elevations. Journal of Ecology, 109(1), 38-50. https://doi.org/10.1111/1365-2745.13440

Fridley, J. D., \& Grime, P. (2010). Community and ecosystem effects of intraspecific genetic diversity in grassland microcosms of varying species diversity. Ecology, 91, 2272-2283. https://doi.org/10.1890/09-1240.1

Gealy, D. R., Rohlla, J. S., \& Boykin, D. L. (2019). Genetic potential of rice under alternate-wettingand-drying irrigation management for barnyardgrass (Echinochloa crus-galli ) suppression and grain yield production. Weed Science, 67, 453-462. https://doi.org/10.1017/wsc.2019.24

Genung, M. A., Bailey, J. K., \& Schweitzer, J. A. (2012). Welcome to the neighborhood: interspecific genotype by genotype interactions inSolidago influence above and belowground biomass and associated communities. Ecology Letters, 15, 65-73. https://doi.org/10.1111/j.1461-0248.2011.01710.x

Gruntman, M., \& Novoplansky, A. (2004). Physiologically mediated self/non-self discrimination in roots. Proceedings of the National Academy of Sciences of the United States of America, 101, 3863-3867. https://doi.org/10.1073/pnas.0306604101 
Hu, L. F., Robert, C. A. M., Cadot, S. C., Zhang, X., Ye, M., Li, B. B., .. Erb M. 2018. Root exudate metabolites drive plant-soil feedbacks on growth and defense by shaping the rhizosphere microbiota. Nature Communications, 9(1), 2738. https://doi.org/10.1038/s41467-018-05122-7

Inderjit, S., Wardle, D. A., Karban, R., \& Callaway, R. M. (2011). The ecosystem and evolutionary contexts of allelopathy. Trends in Ecology and Evolution, 26, 655-662. https://doi.org/10.1016/j.tree.2011.08.003

Kalske, A., Shiojiri, K., Uesugi, A., Sakata, Y., \& Kessler, A. (2019). Insect herbivory selects for volatile-mediated plant-plant communication. Current Biology, 29, 3128-3133. https://doi.org/10.1016/j.cub.2019.08.011

Kato-Noguchi, H. (2011). Barnyard grass-induced rice allelopathy and momilactone B. Journal of Plant Physiology, 168, 1016-1020. https://doi.org/10.1016/j.jplph.2010.12.021

Karban, R., Shiojiri, K., Ishizaki, S., Wetzel, W. C., \& Evans, R. Y. (2013). Kin recognition affects plant communication and defence.Proceedings of the Royal Society B: Biological Sciences, 280, 20123062. https://doi.org/10.1098/rspb.2012.3062

Kong, C. H, Hu, F., Wang, P., \& Wu, J. L. (2008). Effect of allelopathic rice varieties combined with cultural management options on paddy field weeds. Pest Management Science, 64(3), 276-282. https://doi.org/10.1002/ps.1521

Kong, C. H., Li, H. B., Hu, F., Xu, X. H. \& Wang, P. (2006). Allelochemicals released by rice roots and residues in soil. Plant and Soil, 288(1-2), 47-56. https://doi.org/10.1007/s11104-006-9033-3

Kong, C. H., Liang, W. J., Xu, X. H., Hu, F., Wang, P., \& Jiang, Y. (2004). Release and activity of allelochemicals from allelopathic rice seedlings. Journal of Agricultural and Food Chemistry, 52(10), 28612865. https://doi.org/10.1021/jf035467i

Kong, C. H., Zhang, S. Z., Li, Y. H., Xia, Z. C., Yang, X. F., Meiners, S. J., \& Wang, P. (2018). Plant neighbor detection and allelochemical response are driven by root-secreted signaling chemicals. Nature Communications, 9(1), 3867. https://doi.org/10.1038/s41467-018-06429-1

Lankau, R. A., \& Strauss, S. Y. (2007). Mutual feedbacks maintain both genetic and species diversity in a plant community. Science, 317, 1561-1563. https://doi.org/10.1126/science.1147455

Li, L. L., Zhao, H. H., \& Kong, C. H. (2020). (-)-Loliolide, the most ubiquitous lactone, is involved in barnyardgrass-induced rice allelopathy. Journal of Experimental Botany, 71(4), 1540-1550. https://doi.org/10.1093/jxb/erz497

Macias, F. A., Mejias, F. J., \& Molinillo, J. M. (2019). Recent advances in allelopathy for weed control: From knowledge to applications. Pest Management Science, 75(9), 2413-2436. https://doi.org/10.1002/ps.5355

Maron, J. L., Hahn, P. G., Hajek, K. L., \& Pearson, D. E. (2020). Trade-offs between seed size and biotic interactions contribute to coexistence of co-occurring species that vary in fecundity. Journal of Ecology, https://doi.org/10.1111/1365-2745.13491

Meiners, S. J., Kong, C. H., Ladwig, L. M., Pisula, N. L., \& Lang, K. A. (2012). Developing an ecological context for allelopathy. Plant Ecology, 213(8), 1221-1227. https://doi.org/ 10.1007/s11258-012-0078-5

Metlen, K. L., Aschehoug, E. T., \& Callaway, R. M. (2009). Plant behavioural ecology: dynamic plasticity in secondary metabolites. Plant, Cell and Environment, 32(6), 641-653. https://doi.org/10.1111/j.13653040.2008.01910.x

Miki, T., Ushio, M., Fukui, S., \& Kondoh, M. (2010). Functional diversity of microbial decomposers facilitates plant coexistence in a plant-microbe-soil feedback model.Proceedings of the National Academy of Sciences of the United States of America, 107, 14251-14256. https://doi.org/10.1073/pnas.0914281107 
Murphy, G. P., Swanton, C. J., van Acker, R. C., \& Dudley, S. A. (2017). Kin recognition, multilevel selection and altruism in crop sustainability. Journal of Ecology, 105(4), 930-934. https://doi.org/10.1111/13652745.12787

Nourimand, M., \& Todd, C. D. (2016). Allantoin increases cadmium tolerance in Arabidopsis via activation of antioxidant mechanisms. Plant and Cell Physiology, 57(12), 2485-2496. http://doi.org/10.1093/pcp/pcw162

Olofsdotter, M., Navarez, D., Rebulanan, M., \& Streibig, J.C, (1999). Weed suppressing rice cultivars - does allelopathy play a role? Weed Research, 39(6), 441-454. http://doi.org/10.1046/j.1365-3180.1999.00159.x

Ormeno, E., Fernandez, C., \& Mevy, J. P. (2007). Plant coexistence alters terpene emission and content of Mediterranean species.Phytochemistry, 68, 840-852. https://doi.org/10.1016/j.phytochem.2006.11.033

Patni, B., Chandra, H., Mishra, A. P., Guru, S. K., Vitalini, S., \& Iriti, M. (2018). Rice allelopathy in weed management - An integrated approach. Cellular and Molecular Biology, 64, 84-93. https://doi.org/10.14715/cmb/2018.64.8.13

Pierik, R., Mommer, L., \& Voesenek, L. A. C. J. (2013). Molecular mechanisms of plant competition: Neighbour detection and response strategies. Functional Ecology,27(4), 841-853. https://doi.org/10.2307/23480993

Schnitzer, S. A., Klironomos, J. N., Lambers, J., Kinkel, L. L., Reich, P. B., Xiao, K., ...Scheffer M. (2011). Soil microbes drive the classic plant diversity-productivity pattern. Ecology, 92, 296-303. https://doi.org/10.1890/10-0773.1

Semchenko, M., John, E. A., \& Hutchings, M. J. (2007). Effects of physical connection and genetic identity of neighbouring ramets on root placement patterns in two clonal species. New Phytologist,176(3), 644-654. https://doi.org/10.1111/j.1469-8137.2007.02211.x

Semchenko, M., Saar, S., \& Lepik, A. (2014). Plant root exudates mediate neighbour recognition and trigger complex behavioural changes.New Phytologist, 204(3), 631-637. https://doi.org/10.1111/nph.12930

Semchenko, M., Saar, S., \& Lepik, A. 2017. Intraspecific genetic diversity modulates plant-soil feedback and nutrient cycling. New Phytologist, 216(1), 90-98. https://doi.org/10.1111/nph.14653

Serra, N. S., Shanmuganathan, R., \& Becker, C. (2021). Allelopathy in rice: a story on momilactones, kin recognition, and weed management.Journal of Experimental Botany,https://doi.org/10.1093/jxb/erab084

Sun, B., Wang, P., \& Kong, C. H. (2014). Plant-soil feedback in the interference of allelopathic rice with barnyardgrass. Plant and Soil, 377(1), 309-321. https://doi.org/10.1007/s11104-013-2004-6

Takagi, H., Ishiga, Y., Watanabe, S., Konishi, T., Egusa, M., Akiyoshi, N., ...Sakamoto, A. (2016). Allantoin, a stress-related purine metabolite, can activate jasmonate signaling in a MYC2regulated and abscisic acid dependent manner. Journal of Experimental Botany,67(8), 2519-2532. https://doi.org/10.1093/jxb/erw071

Tilman. D., Pacala, S. 1993. The maintenance of species richness in plant communities. In R. E. Ricklefs \& D. Schluter (Eds.),Species diversity in ecological communities: Historical and geographical perspectives . Chicago, IL: University of Chicago Press.

Wang, N. Q., Kong, C. H., Wang, P., \& Meiners, S. J. (2020). Root exudate signals in plant-plant interactions. Plant, Cell and Environment, https://doi.org/10.1111/pce.13892

Wang, P., Kong, C. H., Hu, F., \& Xu, X. H. (2007). Allantoin involved in species interactions with rice and other organisms in paddy soil.Plant and Soil, 296(1-2), 43-51. https://doi.org/10.1007/s11104-007-9288-3

Wang, P., Kong, C. H., Sun, B., \& Xu, X. H. (2010). Allantoin-induced change of microbial diversity and community in rice soil. Plant and Soil, 332(1), 357-368. https://doi.org/10.1007/s11104-010-0301-x 
Xia, Z. C., Kong, C. H., Chen, L. C., Wang, P., \& Wang, S. L. (2016). A broadleaf species enhances an autotoxic conifers growth through belowground chemical interactions. Ecology, 97(9), 2283-2292. https://doi.org/10.1002/ecy.1465

Yamawo, A. (2015). Relatedness of neighboring plants alters the expression of indirect defense traits in an extrafloral nectary-bearing plant. Evolutionary Biology, 42, 12-19. https://doi.org/10.1007/s11692-014$9295-2$

Yamawo, A., \& Mukai, H. (2020). Outcome of interspecific competition depends on genotype of conspecific neighbours. Oecologia, 193, 415-423. https://doi.org/ 10.1007/s00442-020-04694-w

Yang, X. F., \& Kong, C. H. (2017). Interference of allelopathic rice with paddy weeds at the root level. Plant Biology, 19(4), 584-591. https://doi.org/10.1111/plb.12557

Yang, X. F., Li, L. L., Xu, Y., \& Kong, C. H. (2018). Kin recognition in rice (Oryza sativa) lines. New Phytologist, 220(2), 567-578. https://doi.org/ 10.1111/nph.15296

Zhang, L., Liu, Q. Y., Tian, Y. Q., Xu, X. L., \& Ouyang, H. (2016). Kin selection or resource partitioning for growing with siblings: implications from measurements of nitrogen uptake. Plant and Soil 398, 79-86. https://doi.org/ 10.1007/s11104-015-2641-z

Zhang, Z., Liu, Y., Yuan, L., Weber, E., \& van Kleunen, M. (2020). Effect of allelopathy on plant performance: a meta-analysis.Ecology Letters, https://doi.org/ 10.1111/ele.13627

\section{FIGURE LEGENDS}

FIGURE 1 Inhibition of allelopathic rice cultivars 'Huagan-3' and 'Lingyou-6173' mixed with different related cultivars on weed number and biomass (all species pooled) in a paddy field. Closely related cultivars, 'Huagan-8' and 'Lingyou-6365'. Distantly related cultivars, 'Huafeng' and 'Lingyou-3826' (both indica) and Liaojing (japonica). Values were calculated as percentages relative to controls (plots without rice). Columns with different letters indicate significant differences within each cultivar at $P<0.05$ according to ANOVA, followed by Turkey HSD tests.

FIGURE 2 Inhibition of allelopathic rice cultivars 'Huagan-3' and 'Lingyou-6173' mixed with different related cultivars on four paddy weeds and their barnyardgrass-based mixtures. Closely related cultivars, 'Huagan-8' and 'Lingyou-6365'. Distantly related cultivars, 'Huafeng' and 'Lingyou-3826' (both indica) and Liaojing (japonica). Values were calculated as percentages relative to controls (weeds only). Columns with different letters indicate significant differences within the same weeds and their mixtures at $P<0.05$ according to ANOVA, followed by Turkey HSD tests.

FIGURE 3 Root intrusion of allelopathic rice cultivars 'Huagan-3' and 'Lingyou-6173' mixed with different related cultivars in the present of paddy weeds. Closely related cultivars, 'Huagan-8' and 'Lingyou-6365'. Distantly related cultivars, 'Huafeng'and'Lingyou-3826' (both indica) and Liaojing (japonica). Control, allelopathic rice cultivars 'Huagan-3' and 'Lingyou-6173' monocultures in the absence of paddy weeds. Vn/Va values indicate root placement patterns of unresponsive $(\mathrm{Vn} / \mathrm{Va}=1)$, intrusive $(\mathrm{Vn} / \mathrm{Va}>1)$, or avoidance $(\mathrm{Vn} / \mathrm{Va}<1)$.

FIGURE 4 Root avoidance of paddy weeds in response to allelopathic rice cultivars 'Huagan-3' and 'Lingyou-6173' mixed with different related cultivars. Closely related cultivars, 'Huagan-8' and 'Lingyou6365'. Distantly related cultivars, 'Huafeng' and 'Lingyou-3826' (both indica) and Liaojing (japonica). Control, paddy weeds monocultures without any rice cultivars. Vn/Va values indicate root placement patterns of unresponsive $(\mathrm{Vn} / \mathrm{Va}=1)$, intrusive $(\mathrm{Vn} / \mathrm{Va}>1)$, or avoidance $(\mathrm{Vn} / \mathrm{Va}<1)$.

FIGURE 5 Production of allelochemicals (tricin and momilactone B) from allelopathic rice cultivars 'Huagan-3' and 'Lingyou-6173' mixed with different related cultivars in presence of barnyardgrass and barnyardgrass-based weed mixtures. Closely related cultivars, 'Huagan-8' and 'Lingyou-6365'. Distantly related cultivars 'Huafeng' and 'Lingyou-3826' (both indica) and Liaojing (japonica). Values were calculated 
as percent increase above controls (no weeds). Columns with different letters indicate significant differences within barnyardgrass or its mixtures with other weeds at $P<0.05$ according to ANOVA, followed by Turkey HSD tests.

FIGURE 6 Plots of principal components analysis of PLFA composition in the soils grown by focal rice cultivar 'Huagan-3', 'Lingyou-6173' or barnyardgrass monocultures and their mixed-cultures. Data used in PCA plots were transformed using sample unit totals to represent the relative abundance of each PLFA (mole percentage of total PLFA).

FIGURE 7 Inhibition of barnyardgrass by allelopathic rice cultivars 'Huagan-3' and 'Lingyou-6173' mixed with different related cultivars under applied $\mathrm{NH}_{4} \mathrm{NO}_{3}$ and allantoin. Closely related cultivars, 'Huagan-8' and 'Lingyou-6365'. Distantly related cultivars, 'Huafeng' and 'Lingyou-3826' (both indica) and Liaojing (japonica). Values were calculated as $\%$ reduction relative to controls (no rice). Columns with different letters indicate significant differences at $P<0.05$ among different related cultivar in the same nitrogen treatment according to ANOVA, followed by Turkey HSD tests.

FIGURE 8 Root/shoot carbon and nitrogen ratios of barnyardgrass in the presence of allelopathic rice cultivars 'Huagan-3' and 'Lingyou-6173' mixed with different related cultivars under applied $\mathrm{NH}_{4} \mathrm{NO}_{3}$ and allantoin. Closely related cultivars, 'Huagan-8' and 'Lingyou-6365'. Distantly related cultivars, 'Huafeng' and 'Lingyou-3826' (both indica) and Liaojing (japonica). Control, barnyardgrass monocultures.

Supplementary Figure 1 Pot experiments for the performance of weeds by allelopathic rice cultivars mixed with different related cultivars at seedling stage. Control refers weed monocultures. Only barnyardgrass is shown here.

Supplementary Figure 2 Rhizobox experiments for the root placement pattern of weeds in the presence of allelopathic rice cultivars mixed with different related cultivars at seedling stage. Top panel illustrates the planting design in an individual rhizobox. Control refers to weed monoculture. Only barnyardgrass is shown here.

Supplementary Figure 3 Distribution of root length and biomass of allelopathic rice cultivars 'Huagan-3' and 'Lingyou-6173' mixed with different related cultivars in the presence of paddy weeds. Closely related cultivars, 'Huagan-8' and 'Lingyou-6365'. Distantly related cultivars, 'Huafeng' and 'Lingyou-3826' (both indica) and Liaojing (japonica). Columns with different letters indicate significant differences within each weed at $P<0.05$ according to ANOVA, followed by Turkey HSD tests.

Supplementary Figure 4 Distribution of root length and biomass of paddy weeds in response to allelopathic rice cultivars 'Huagan-3' and 'Lingyou-6173' mixed with different related cultivars. Closely related cultivars, 'Huagan-8' and 'Lingyou-6365'. Distantly related cultivars, 'Huafeng'and'Lingyou-3826' (both indica) and Liaojing (japonica). Columns with different letters indicate significant differences within each weed at $P<0.05$ according to ANOVA, followed by Turkey HSD tests.

Supplementary Figure 5 Inhibition of allelopathic rice cultivars 'Huagan-3' and 'Lingyou-6173' mixed with different related cultivars on barnyardgrass and barnyardgrass-based weed mixtures at rice mature stage. Closely related cultivars, 'Huagan-8' and 'Lingyou-6365'. Distantly related cultivars 'Huafeng' and 'Lingyou-3826' (both indica) and Liaojing (japonica). Values were calculated as percentages relative to controls (weeds only). Columns with different letters indicate significant differences within barnyardgras or its mixtures with other weeds at $P<0.05$ according to ANOVA, followed by Turkey HSD tests.

Supplementary Figure 6 Grain biomass of allelopathic rice cultivars 'Huagan-3' and 'Lingyou-6173' mixed with different related cultivars in presence of barnyardgrass and barnyardgrass-based weed mixtures. Closely related cultivars, 'Huagan-8' and 'Lingyou-6365'. Distantly related cultivars 'Huafeng' and 'Lingyou-3826' (both indica) and Liaojing (japonica). Columns with different letters indicate significant differences within barnyardgras or its mixtures with other weeds at $P<0.05$ according to ANOVA, followed by Turkey HSD tests. 
Supplementary Figure 7 Relative abundance of bacterial, fungal, actinobacterial PLFAs in the soils grown by focal rice cultivar 'Huagan-3', 'Lingyou-6173' or barnyardgrass monocultures and their mixed-cultures. Closely related cultivars, 'Huagan-8' and 'Lingyou-6365'. Distantly related cultivars, 'Huafeng', 'Lingyou3826' (both indica) and Liaojing (japonica). Columns with different letters indicate significant differences within the same PLFA at $P<0.05$ according to ANOVA, followed by Turkey HSD tests.
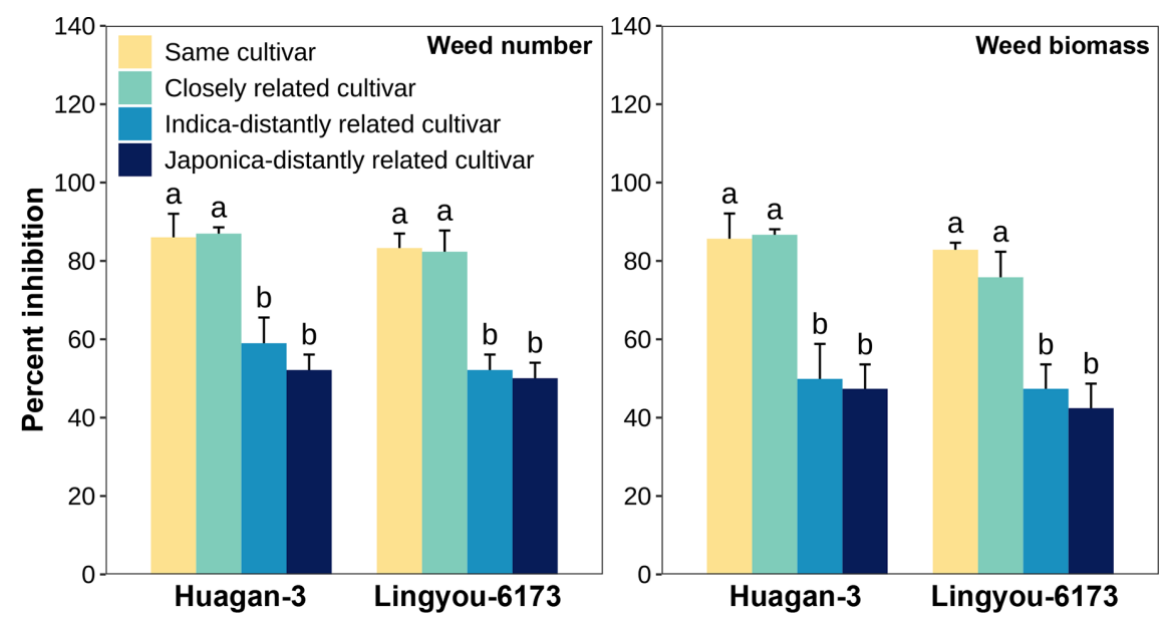

FIGURE 1 Inhibition of allelopathic rice cultivars 'Huagan-3' and 'Lingyou-6173' mixed with different related cultivars on weed number and biomass (all species pooled) in a paddy field

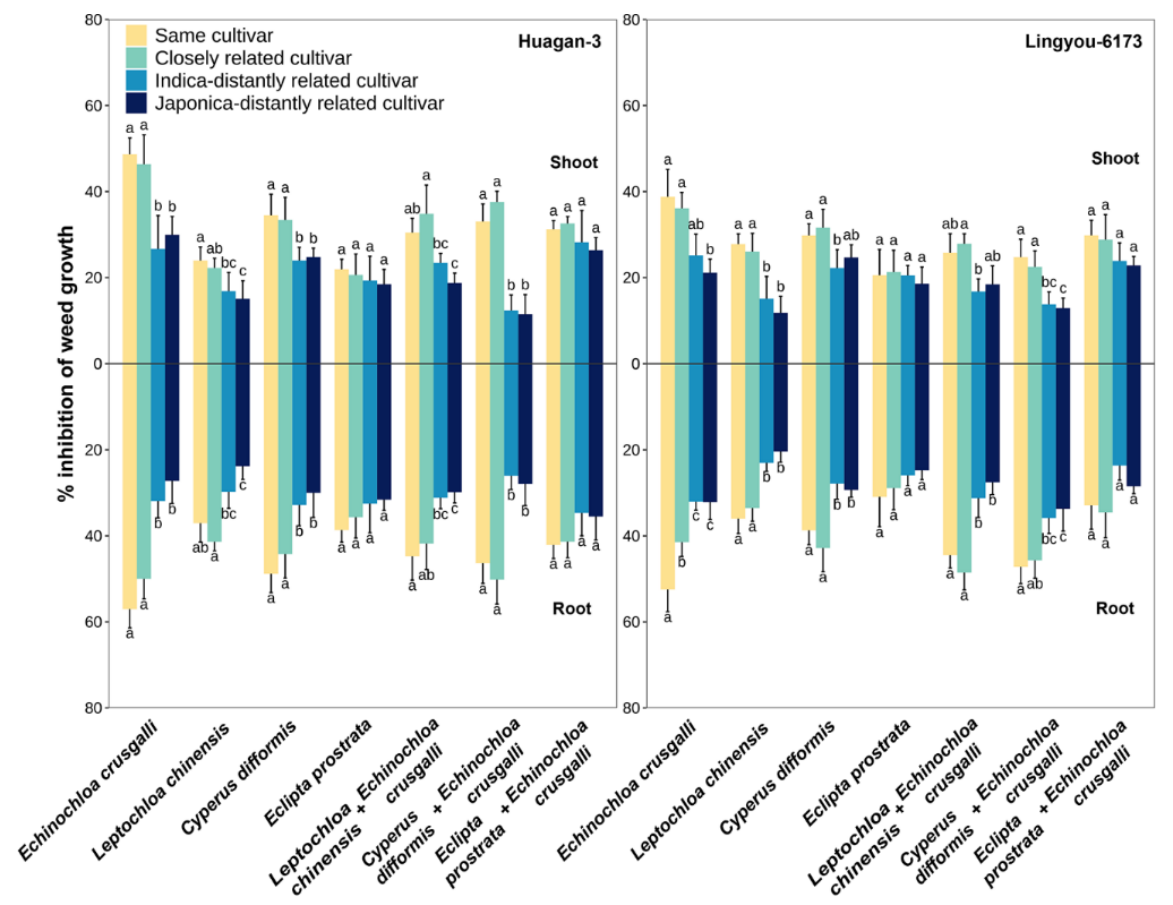

FIGURE 2 Inhibition of allelopathic rice cultivars 'Huagan-3' and 'Lingyou-6173' mixed with different related cultivars on four paddy weeds and their barnyardgrass-based mixtures 


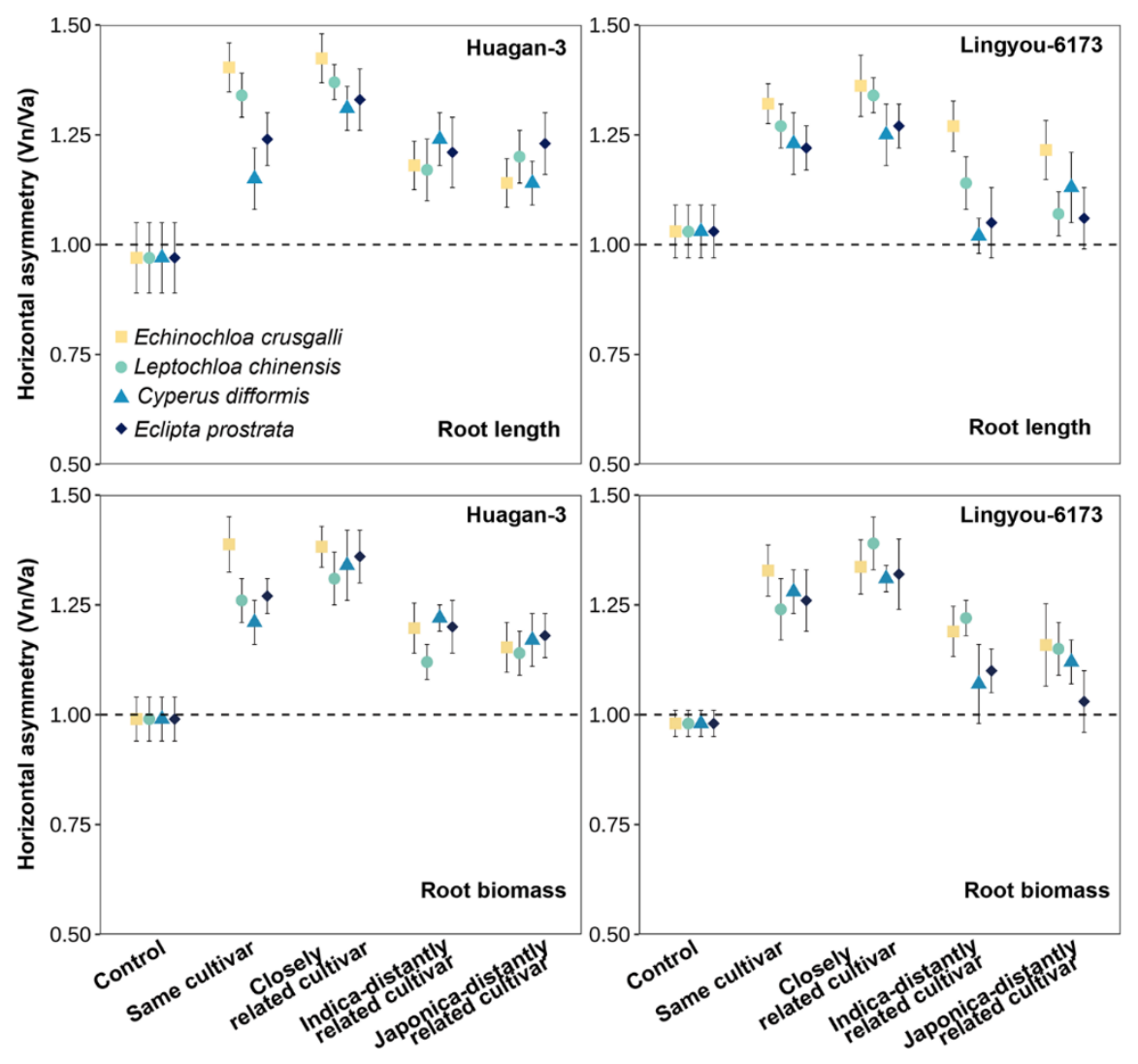

FIGURE 3 Root intrusion of allelopathic rice cultivars 'Huagan-3' and 'Lingyou-6173' mixed with different related cultivars in the present of paddy weeds 


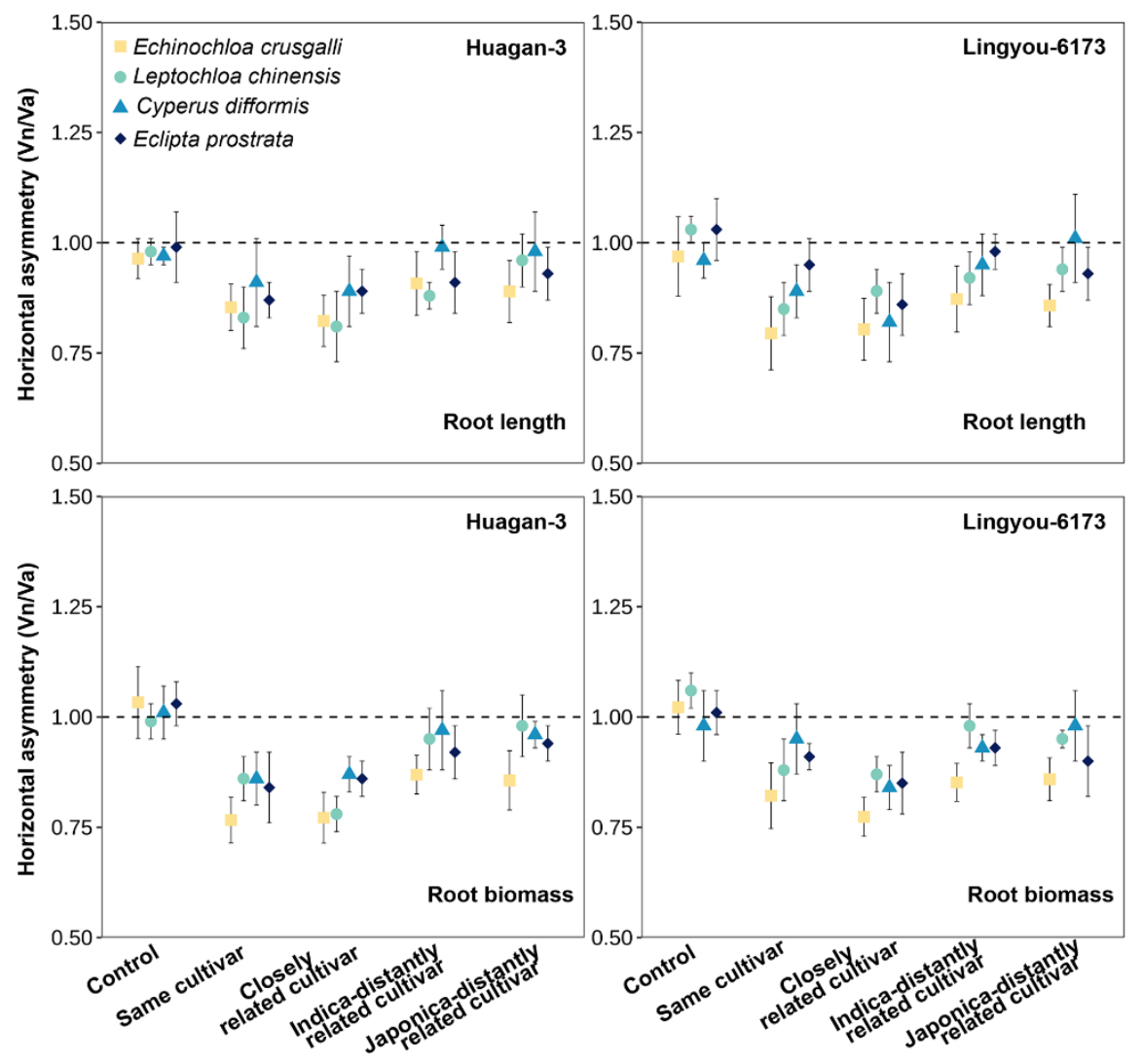

FIGURE 4 Root avoidance of paddy weeds in response to allelopathic rice cultivars 'Huagan-3' and 'Lingyou-6173' mixed with different related cultivars

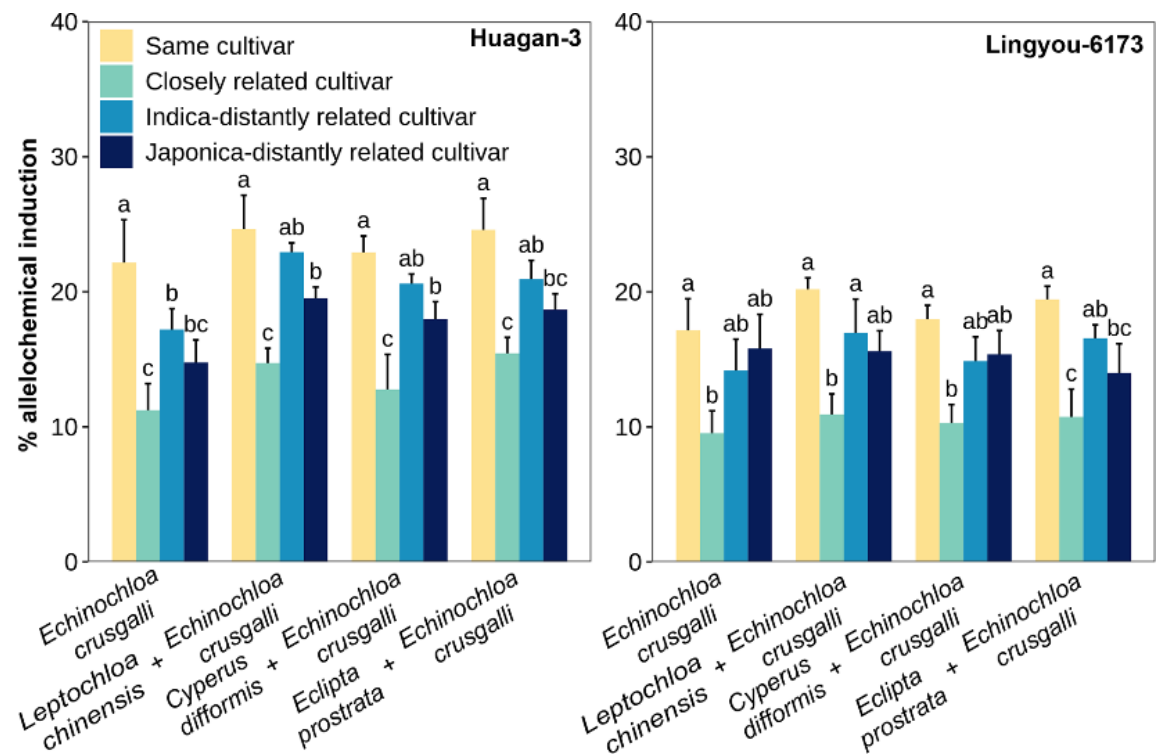

FIGURE 5Production of allelochemicals (tricin and momilactone B) from allelopathic rice cultivars 'Huagan-3' and 'Lingyou-6173' mixed with different related cultivars in presence of barnyardgrass and 
barnyardgrass-based weed mixtures
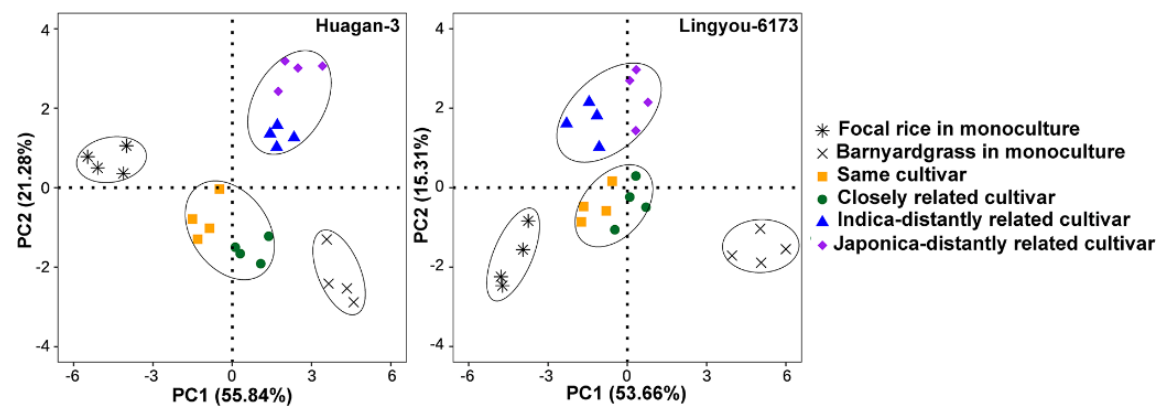

FIGURE 6 Plots of principal components analysis of PLFA composition in the soils grown by focal rice cultivar 'Huagan-3', 'Lingyou-6173' or barnyardgrass monocultures and their mixed-cultures

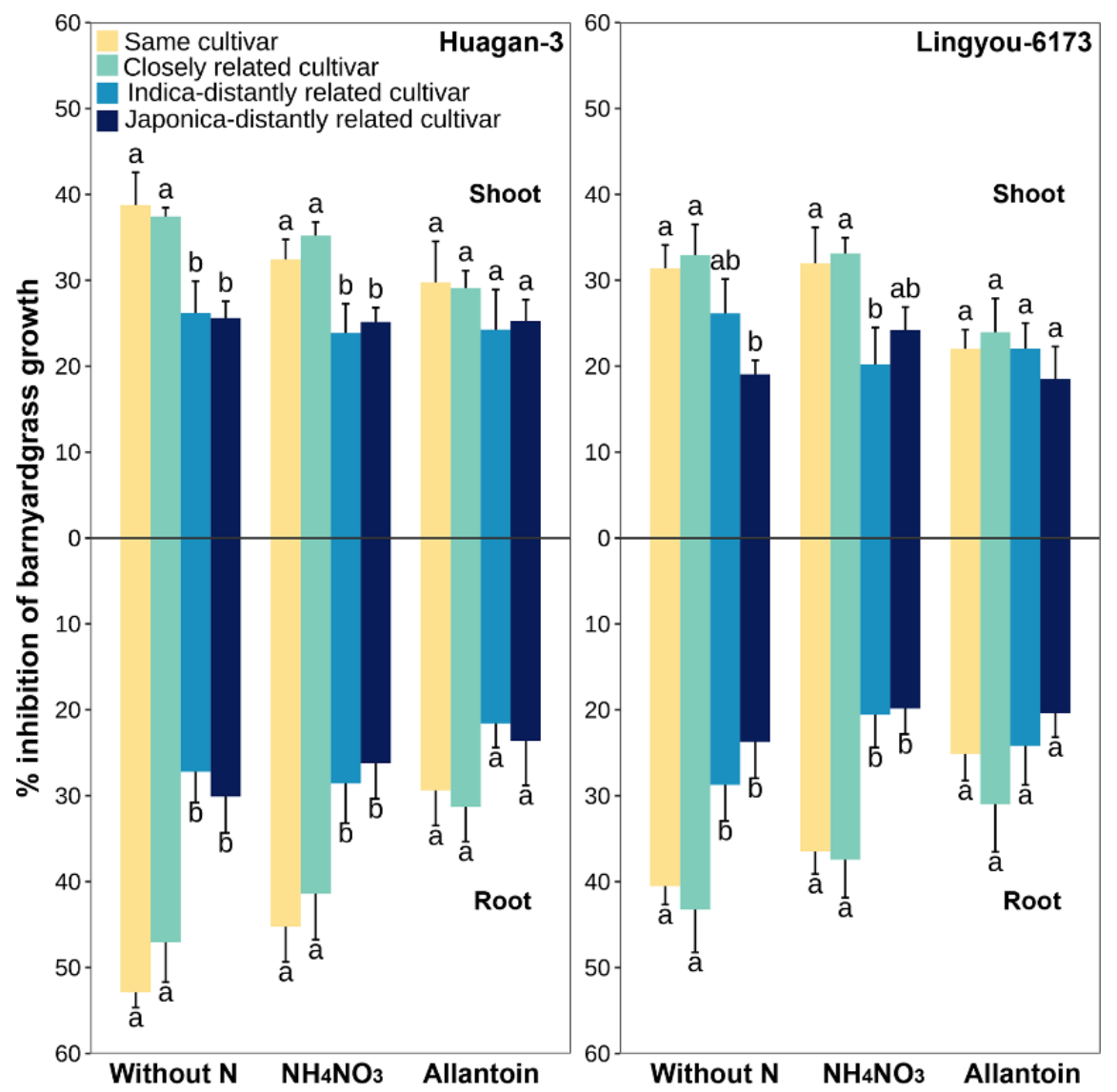

FIGURE 7 Inhibition of barnyardgrass by allelopathic rice cultivars 'Huagan-3' and 'Lingyou-6173' mixed with different related cultivars under applied $\mathrm{NH}_{4} \mathrm{NO}_{3}$ and allantoin 


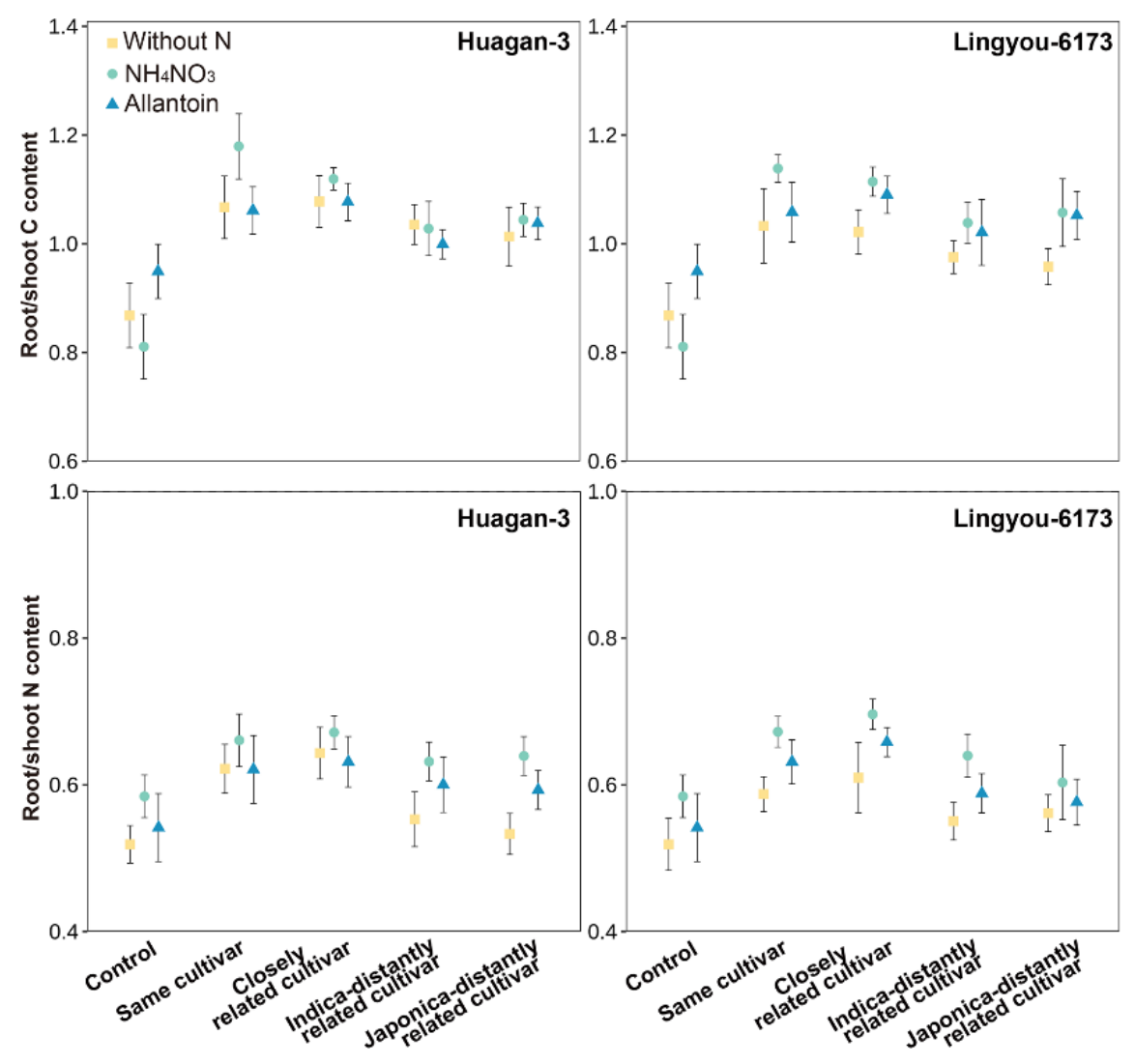

FIGURE 8 Root/shoot carbon and nitrogen ratios of barnyardgrass in the presence of allelopathic rice cultivars 'Huagan-3' and 'Lingyou-6173' mixed with different related cultivars under applied $\mathrm{NH}_{4} \mathrm{NO}_{3}$ and allantoin.

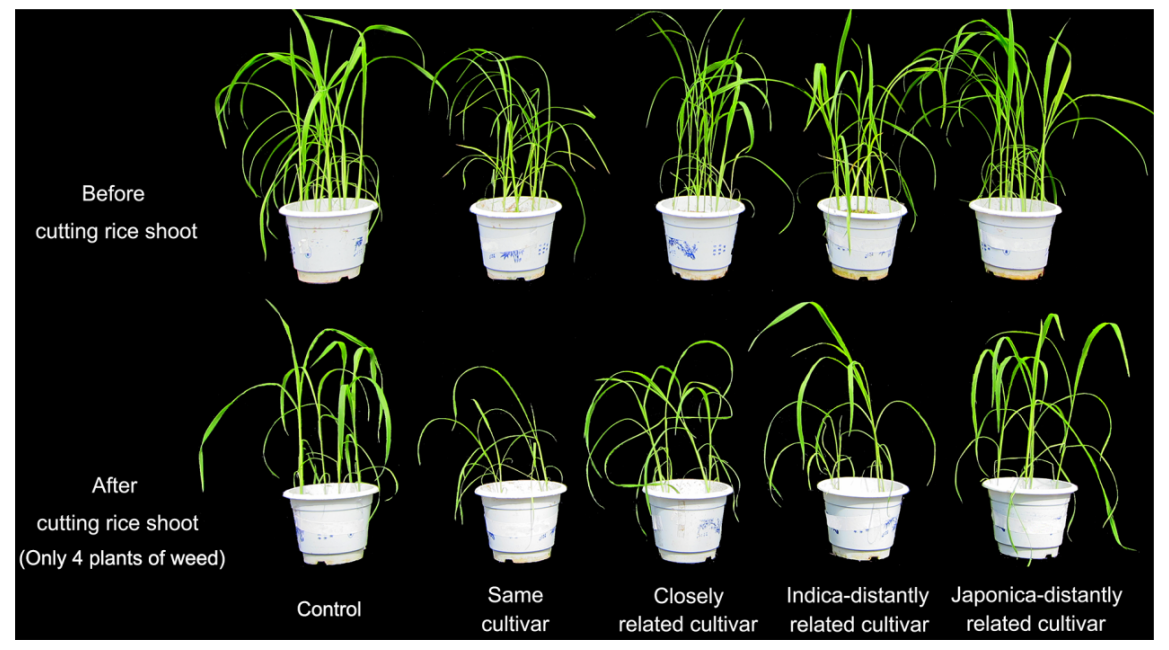

Supplementary Figure 1 Pot experiments for the performance of weeds by allelopathic rice cultivars mixed with different related cultivars at seedling stage. 

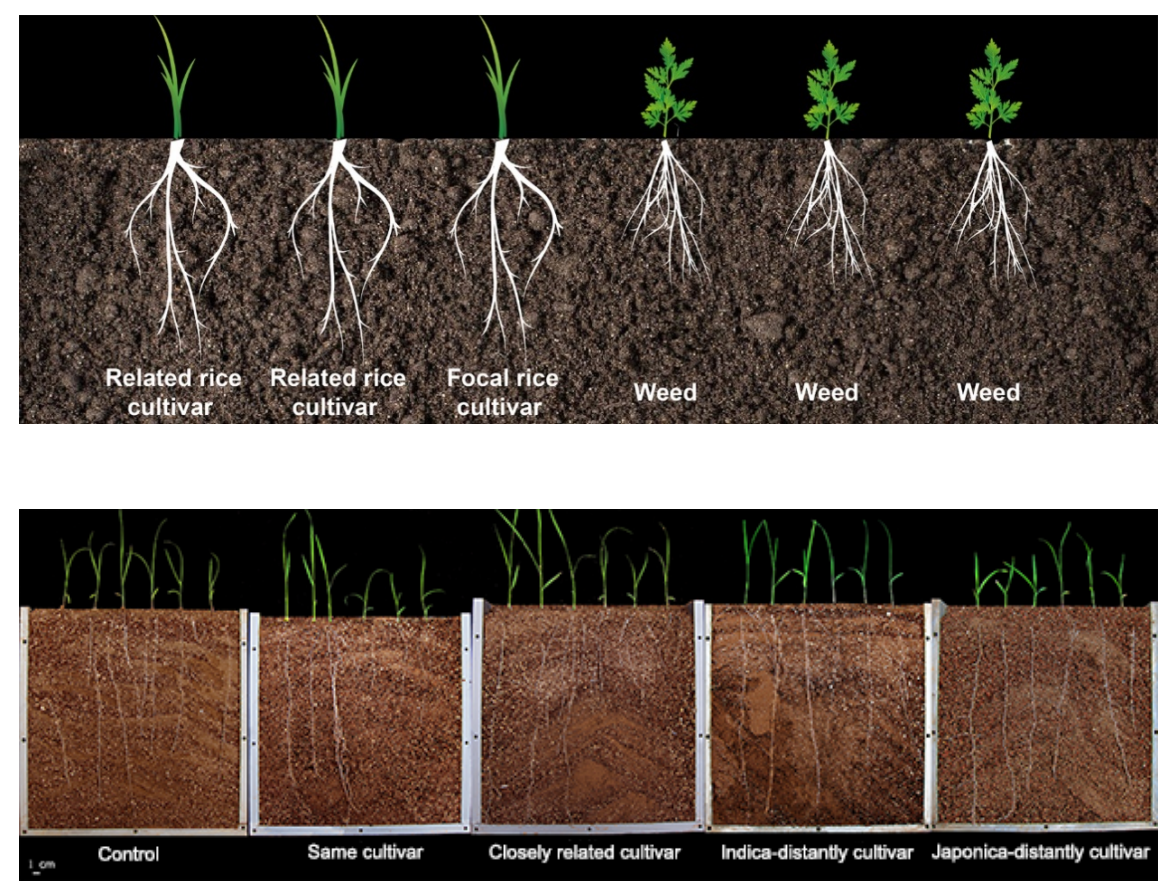

Supplementary Figure 2 Rhizobox experiments for the root placement pattern of weeds in the presence of allelopathic rice cultivars mixed with different related cultivars at seedling stage

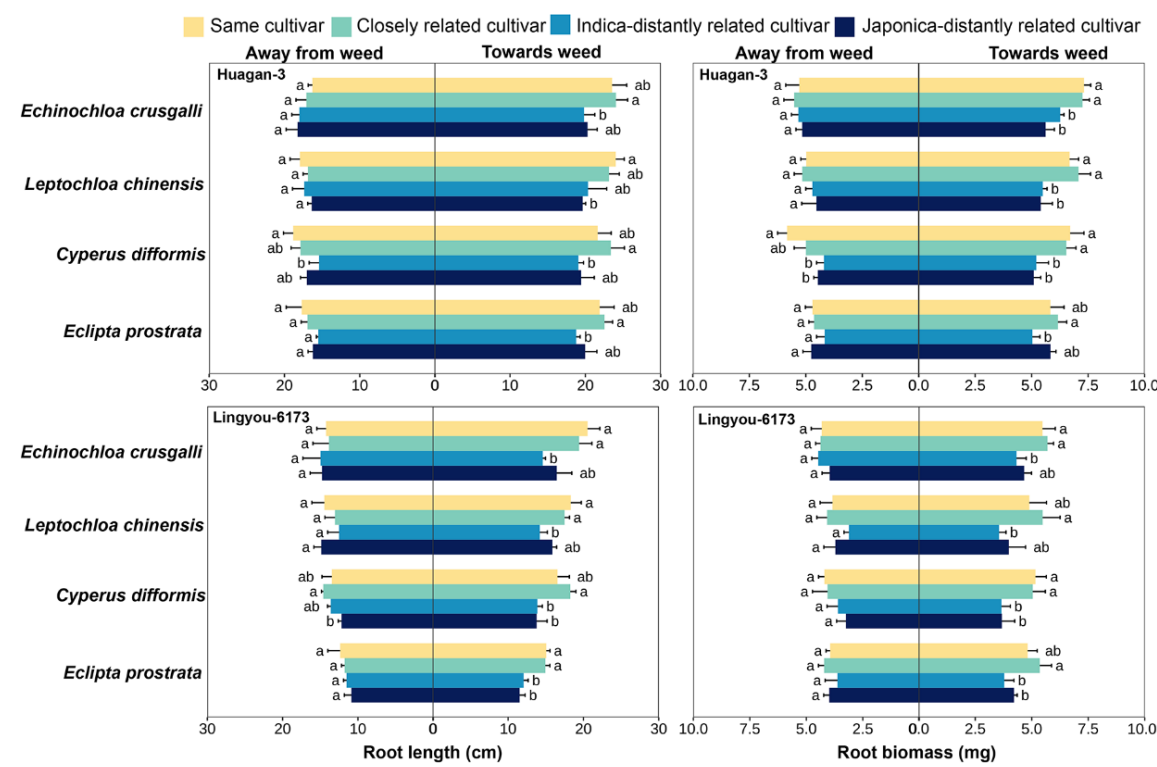

Supplementary Figure 3Distribution of root length and biomass of allelopathic rice cultivars 'Huagan-3' and 'Lingyou-6173' mixed with different related cultivars in the presence of paddy weeds 


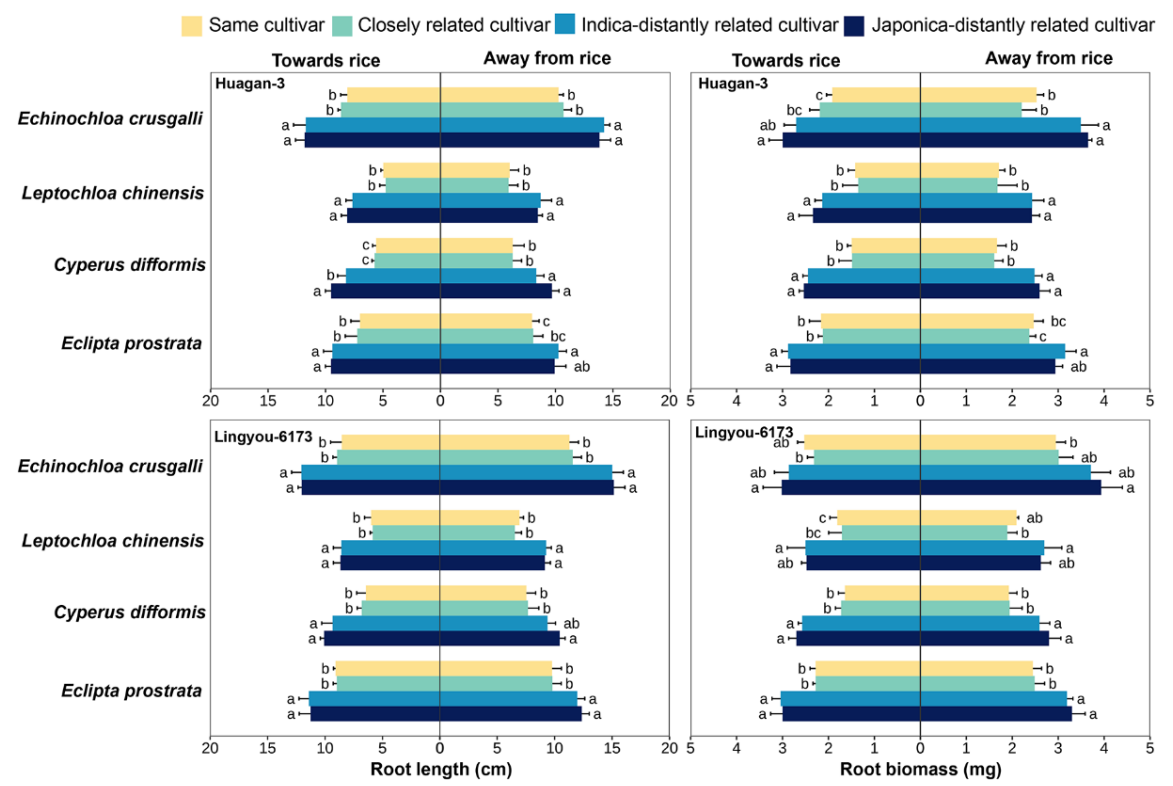

Supplementary Figure 4 Distribution of root length and biomass of paddy weeds in response to allelopathic rice cultivars 'Huagan-3' and 'Lingyou-6173' mixed with different related cultivars

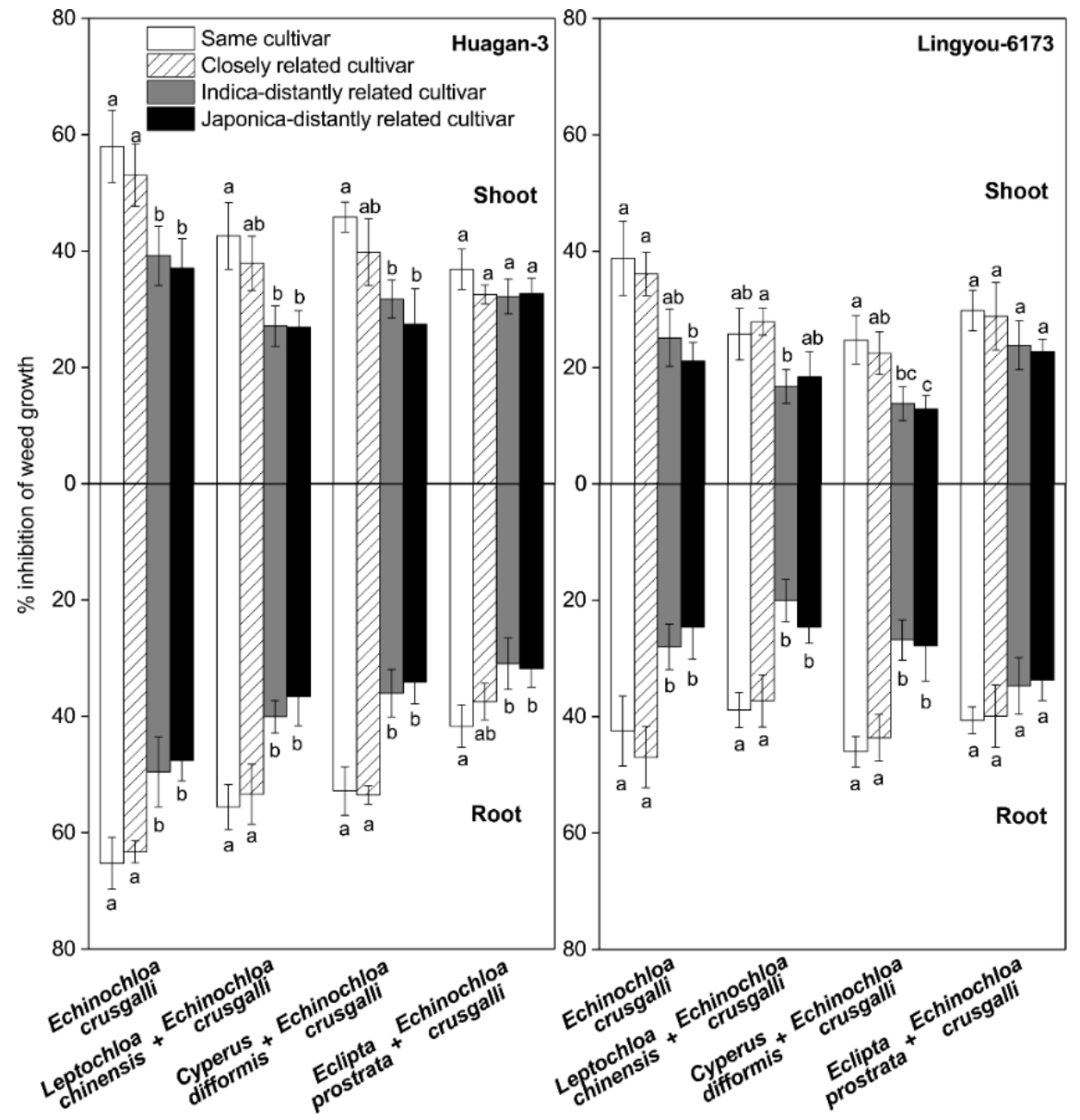


Supplementary Figure 5 Inhibition of allelopathic rice cultivars 'Huagan-3' and 'Lingyou-6173' mixed with different related cultivars on barnyardgrass and barnyardgrass-based weed mixtures at rice mature stage

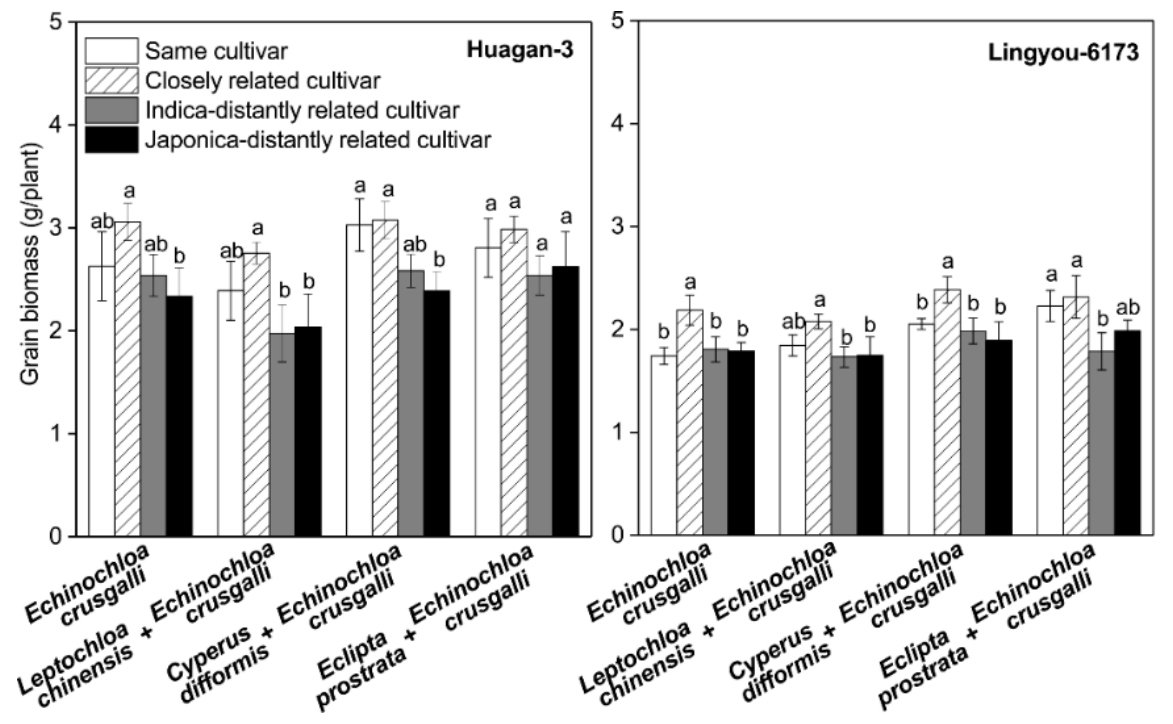

Supplementary Figure 6Grain biomass of allelopathic rice cultivars 'Huagan-3' and 'Lingyou-6173' mixed with different related cultivars in presence of barnyardgrass and barnyardgrass-based weed mixtures

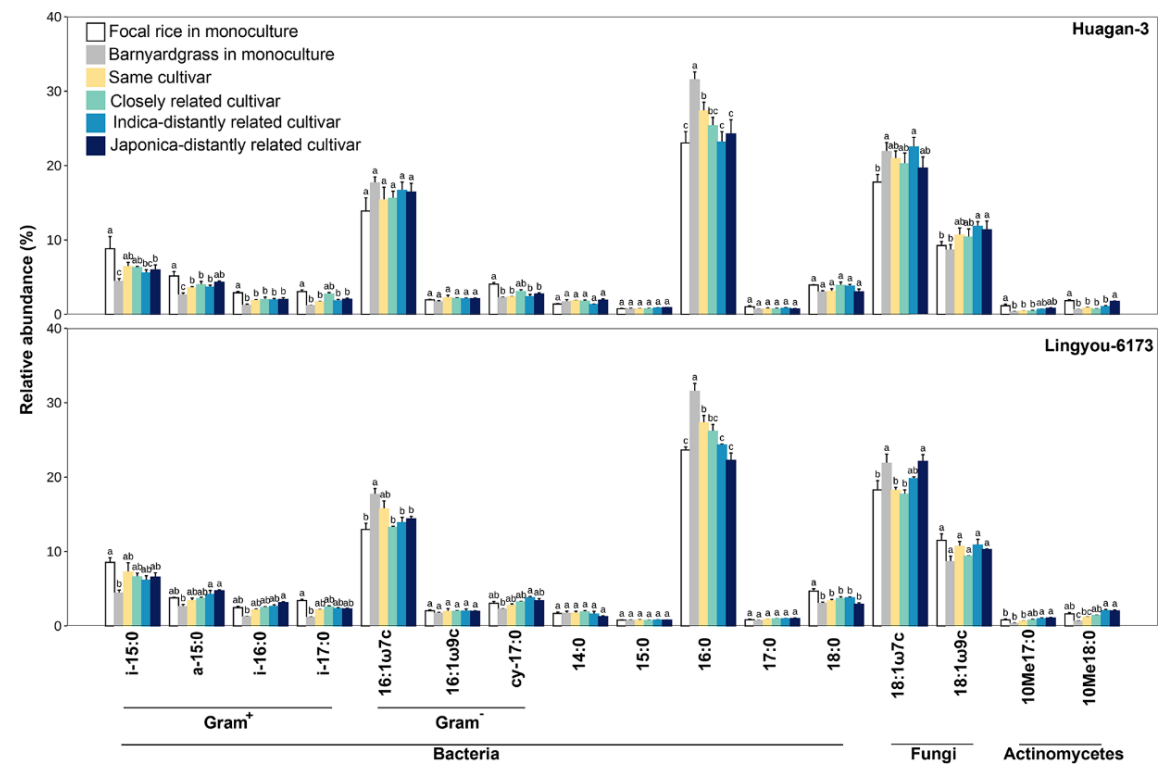

Supplementary Figure 7 Relative abundance of bacterial, fungal, actinobacterial PLFAs in the soils grown by focal rice cultivar 'Huagan-3', 'Lingyou-6173' or barnyardgrass monocultures and their mixed-cultures

Supplementary Table 1 The genetic distance, allelopathic potential and grain biomass of rice cultivars tested 


\begin{tabular}{|c|c|c|c|c|c|}
\hline Genotype & Cultivar & $\begin{array}{l}\text { Genetic } \\
\text { distance }\end{array}$ & $\begin{array}{l}\text { Allelochemical } \\
\text { induction ( } \% \\
\text { of control) }\end{array}$ & $\begin{array}{l}\text { Weed } \\
\text { inhibition (\% } \\
\text { of control) }\end{array}$ & $\begin{array}{l}\text { Grain biomass } \\
\text { (g/plant) }\end{array}$ \\
\hline \multirow[t]{3}{*}{ Indica-inbred } & Huagan-3 & 1.00 & $57.44 \pm 6.31 \mathrm{a}$ & $64.17 \pm 3.67 \mathrm{a}$ & $2.63 \pm 0.33 \mathrm{a}$ \\
\hline & Huagan-8 & 0.78 & $36.70 \pm 3.57 \mathrm{~b}$ & $37.51 \pm 4.24 \mathrm{~b}$ & $1.64 \pm 0.14 \mathrm{~b}$ \\
\hline & Huafeng & 0.60 & $31.86 \pm 4.08 \mathrm{~b}$ & $33.28 \pm 3.19 \mathrm{~b}$ & $1.34 \pm 0.17 \mathrm{~b}$ \\
\hline $\begin{array}{l}\text { Japonica- } \\
\text { inbred }\end{array}$ & Liaojing & 0.54 & $30.16 \pm 4.29 \mathrm{~b}$ & $8.49 \pm 1.79 \mathrm{c}$ & $1.13 \pm 0.12 \mathrm{~b}$ \\
\hline \multirow[t]{3}{*}{ Indica-hybrid } & Lingyou-6173 & 1.00 & $47.27 \pm 5.65 \mathrm{a}$ & $36.90 \pm 3.78 \mathrm{a}$ & $1.24 \pm 0.13 \mathrm{~b}$ \\
\hline & Lingyou-6365 & 0.85 & $33.91 \pm 3.21 \mathrm{~b}$ & $20.72 \pm 1.55 \mathrm{~b}$ & $1.32 \pm 0.12 \mathrm{~b}$ \\
\hline & Lingyou-3826 & 0.67 & $35.32 \pm 5.81 \mathrm{~b}$ & $15.73 \pm 2.01 \mathrm{~b}$ & $2.11 \pm 0.15 \mathrm{a}$ \\
\hline $\begin{array}{l}\text { Japonica- } \\
\text { inbred }\end{array}$ & Liaojing & 0.42 & $30.16 \pm 4.29 \mathrm{~b}$ & $8.49 \pm 1.79 \mathrm{c}$ & $1.13 \pm 0.12 \mathrm{~b}$ \\
\hline
\end{tabular}

Columns with different letters indicate significant differences within indica-inbred set or and indica-hybrid set at $P<0.05$ according to ANOVA, followed by Turkey HSD tests.

Supplementary Table 2 Preliminary experiment to determine inhibition (\%) of allelopathic rice cultivars 'Huagan-3' and 'Lingyou-6173' mixed culture with the same cultivars 'Huagan-3' and 'Lingyou-6173', closely related cultivars 'Huagan-8' and 'Lingyou-6365' and distantly related cultivars 'Huafeng' and 'Lingyou-3826' (both indica) and Liaojing (japonica) on four paddy weeds at different mixture proportions.

\begin{tabular}{|c|c|c|c|c|c|c|c|c|}
\hline $\begin{array}{l}\text { Cultivar } \\
\text { mix- } \\
\text { ture } \\
\text { proportion }\end{array}$ & $\begin{array}{l}\text { Cultivar } \\
\text { relat- } \\
\text { edness } \\
\text { (a) }\end{array}$ & $\begin{array}{l}\text { Huagan- } \\
3\end{array}$ & $\begin{array}{l}\text { Huagan- } \\
3\end{array}$ & $\begin{array}{l}\text { Huagan- } \\
3\end{array}$ & $\begin{array}{l}\text { Huagan- } \\
3\end{array}$ & $\begin{array}{l}\text { Lingyou- } \\
6173\end{array}$ & $\begin{array}{l}\text { Lingyou- } \\
6173\end{array}$ & $\begin{array}{l}\text { Lingyou- } \\
6173\end{array}$ \\
\hline & & Echinochloa & Leptochloa & Cyperus & Eclipta & Echinochloa & Leptochloa & Cyperus \\
\hline & & crusgalli & chinensis & difformis & prostrata & crusgalli & chinensis & difformis \\
\hline \multirow[t]{8}{*}{$3: 1$} & Same & $52.20 \pm 4.82$ & $26.58 \pm 1.64$ & $37.36 \pm 4.78$ & $25.39 \pm 2.80$ & $41.62 \pm 4.99$ & $29.44 \pm 2.58$ & $31.39 \pm 3.54$ \\
\hline & cultivar & $\mathrm{a}$ & $\mathrm{a}$ & $\mathrm{a}$ & $\mathrm{a}$ & $\mathrm{a}$ & $\mathrm{a}$ & $\mathrm{a}$ \\
\hline & Closely & $49.81 \pm 3.50$ & $28.56 \pm 2.72$ & $37.93 \pm 3.25$ & $27.09 \pm 3.42$ & $43.42 \pm 3.98$ & $26.41 \pm 3.64$ & $32.27 \pm 5.33$ \\
\hline & $\begin{array}{l}\text { related } \\
\text { cultivar }\end{array}$ & $\mathrm{a}$ & $\mathrm{a}$ & $\mathrm{a}$ & $\mathrm{a}$ & $\mathrm{a}$ & $a b$ & $\mathrm{a}$ \\
\hline & Indica- & $44.30 \pm 4.31$ & $25.44 \pm 3.92$ & $30.79 \pm 4.96$ & $26.51 \pm 2.82$ & $40.04 \pm 5.83$ & $21.92 \pm 2.44$ & $28.05 \pm 5.16$ \\
\hline & $\begin{array}{l}\text { distantly } \\
\text { related } \\
\text { cultivar }\end{array}$ & $\mathrm{a}$ & $\mathrm{a}$ & $\mathrm{a}$ & $\mathrm{a}$ & $\mathrm{a}$ & $\mathrm{b}$ & $\mathrm{a}$ \\
\hline & Japonica- & $48.02 \pm 2.15$ & $23.31 \pm 2.10$ & $31.10 \pm 1.42$ & $22.17 \pm 1.73$ & $41.64 \pm 5.06$ & $22.10 \pm 2.60$ & $29.12 \pm 1.95$ \\
\hline & $\begin{array}{l}\text { distantly } \\
\text { related } \\
\text { cultivar }\end{array}$ & $\mathrm{a}$ & $\mathrm{a}$ & $\mathrm{a}$ & $\mathrm{b}$ & $\mathrm{a}$ & $a b$ & $\mathrm{a}$ \\
\hline \multirow[t]{6}{*}{$2: 2$} & Same & $52.20 \pm 4.82$ & $26.58 \pm 1.64$ & $37.36 \pm 4.78$ & $25.39 \pm 2.80$ & $41.62 \pm 4.99$ & $29.44 \pm 2.58$ & $31.39 \pm 3.54$ \\
\hline & cultivar & $\mathrm{a}$ & $\mathrm{a}$ & $\mathrm{a}$ & $\mathrm{a}$ & $\mathrm{a}$ & $\mathrm{a}$ & $\mathrm{a}$ \\
\hline & Closely & $50.71 \pm 2.69$ & $25.72 \pm 2.47$ & $35.57 \pm 5.31$ & $23.46 \pm 1.52$ & $39.38 \pm 3.33$ & $27.50 \pm 2.26$ & $34.13 \pm 4.81$ \\
\hline & $\begin{array}{l}\text { related } \\
\text { cultivar }\end{array}$ & $\mathrm{a}$ & $\mathrm{a}$ & $\mathrm{a}$ & $\mathrm{a}$ & $\mathrm{a}$ & $\mathrm{a}$ & $\mathrm{a}$ \\
\hline & Indica- & $35.15 \pm 5.47$ & $18.26 \pm 3.49$ & $23.62 \pm 4.24$ & $20.82 \pm 2.58$ & $29.92 \pm 3.56$ & $16.67 \pm 2.54$ & $21.98 \pm 2.36$ \\
\hline & $\begin{array}{l}\text { distantly } \\
\text { related } \\
\text { cultivar }\end{array}$ & $\mathrm{b}$ & & $\mathrm{b}$ & $\mathrm{a}$ & & & $\mathrm{b}$ \\
\hline
\end{tabular}




\begin{tabular}{|c|c|c|c|c|c|c|c|c|}
\hline $\begin{array}{l}\text { Cultivar } \\
\text { mix- } \\
\text { ture } \\
\text { proportion }\end{array}$ & $\begin{array}{l}\text { Cultivar } \\
\text { relat- } \\
\text { edness } \\
\text { (a) }\end{array}$ & $\begin{array}{l}\text { Huagan- } \\
3\end{array}$ & $\begin{array}{l}\text { Huagan- } \\
3\end{array}$ & $\begin{array}{l}\text { Huagan- } \\
3\end{array}$ & $\begin{array}{l}\text { Huagan- } \\
3\end{array}$ & $\begin{array}{l}\text { Lingyou- } \\
6173\end{array}$ & $\begin{array}{l}\text { Lingyou- } \\
6173\end{array}$ & $\begin{array}{l}\text { Lingyou- } \\
6173\end{array}$ \\
\hline & $\begin{array}{l}\text { Japonica- } \\
\text { distantly } \\
\text { related } \\
\text { cultivar }\end{array}$ & $\begin{array}{l}35.96 \pm 7.26 \\
\mathrm{~b}\end{array}$ & $\begin{array}{l}17.52 \pm 3.67 \\
\mathrm{~b}\end{array}$ & $\begin{array}{l}24.49 \pm 4.70 \\
\mathrm{~b}\end{array}$ & $\begin{array}{l}20.55 \pm 1.65 \\
\mathrm{a}\end{array}$ & $\begin{array}{l}28.50 \pm 4.04 \\
\mathrm{~b}\end{array}$ & $\begin{array}{l}13.48 \pm 1.61 \\
b\end{array}$ & $\begin{array}{l}22.20 \pm 2.23 \\
\mathrm{~b}\end{array}$ \\
\hline \multirow[t]{5}{*}{$1: 3$} & Same & $52.20 \pm 4.82$ & $26.58 \pm 1.64$ & $37.36 \pm 4.78$ & $25.39 \pm 2.80$ & $41.62 \pm 4.99$ & $29.44 \pm 2.58$ & $31.39 \pm 2.54$ \\
\hline & cultivar & $\mathrm{a}$ & $\mathrm{a}$ & $\mathrm{a}$ & $\mathrm{a}$ & $\mathrm{a}$ & $\mathrm{a}$ & a \\
\hline & $\begin{array}{l}\text { Closely } \\
\text { related } \\
\text { cultivar }\end{array}$ & $\begin{array}{l}46.20 \pm 4.97 \\
\mathrm{ab}\end{array}$ & $\begin{array}{l}19.94 \pm 2.47 \\
\mathrm{ab}\end{array}$ & $\begin{array}{l}29.17 \pm 4.10 \\
\mathrm{ab}\end{array}$ & $\begin{array}{l}19.83 \pm 2.81 \\
\mathrm{ab}\end{array}$ & $\begin{array}{l}34.27 \pm 2.07 \\
\mathrm{ab}\end{array}$ & $\begin{array}{l}19.42 \pm 2.91 \\
\mathrm{~b}\end{array}$ & $\begin{array}{l}24.43 \pm 2.80 \\
\mathrm{~b}\end{array}$ \\
\hline & $\begin{array}{l}\text { Indica- } \\
\text { distantly } \\
\text { related } \\
\text { cultivar }\end{array}$ & $\begin{array}{l}32.21 \pm 4.28 \\
\mathrm{~b}\end{array}$ & $\begin{array}{l}17.64 \pm 3.53 \\
\mathrm{~b}\end{array}$ & $\begin{array}{l}21.63 \pm 5.60 \\
b\end{array}$ & $\begin{array}{l}19.23 \pm 2.48 \\
\mathrm{ab}\end{array}$ & $\begin{array}{l}26.02 \pm 1.51 \\
b\end{array}$ & $\begin{array}{l}18.08 \pm 2.93 \\
b\end{array}$ & $\begin{array}{l}22.23 \pm 3.52 \\
\mathrm{~b}\end{array}$ \\
\hline & $\begin{array}{l}\text { Japonica- } \\
\text { distantly } \\
\text { related } \\
\text { cultivar }\end{array}$ & $\begin{array}{l}38.65 \pm 7.97 \\
\mathrm{ab}\end{array}$ & $\begin{array}{l}16.79 \pm 4.59 \\
b\end{array}$ & $\begin{array}{l}22.93 \pm 5.12 \\
\mathrm{~b}\end{array}$ & $\begin{array}{l}17.28 \pm 3.05 \\
\mathrm{~b}\end{array}$ & $\begin{array}{l}30.61 \pm 4.36 \\
\mathrm{~b}\end{array}$ & $\begin{array}{l}17.31 \pm 3.24 \\
b\end{array}$ & $\begin{array}{l}23.39 \pm 2.17 \\
\mathrm{~b}\end{array}$ \\
\hline
\end{tabular}

(a) Rice cultivar mixtures are associated with four plants of each weed. Columns with different letters indicate significant differences within the same cultivar mixture proportion at $P<0.05$ according to ANOVA, followed by Turkey HSD tests. 